\title{
Epistemicity in Mubarak's and Al-Adly's Testimonies in the "Storming Prisons and Eastern Borders" case: The Knowing, Unknowing and Believing Positions
}

\author{
Dr. Marwa Mohamed Khamis \\ Associate Professor - English Department \\ Faculty of Arts, Alexandria University
}

\begin{abstract}
The present study examines the testimonies of former President Mohamed Hosni Mubarak and former Minister of the Interior, Habib Al-Adly, in the case of storming Egyptian prisons and Eastern borders during the 2011 events in Egypt. By employing the Griffiths Question Map developed by Griffiths and Milne (2006) and Zuczkowski et al.'s (2014) Knowing, Unknowing and Believing model, the study examines the types of questions asked to Mubarak and Al-Adly in the case in question. It also investigates how both witnesses construct epistemicity in their testimonies as well as the relation between the types of questions asked and the epistemic positions adopted by Mubarak and Al-Adly in their testimonies. Results reveal that both witnesses received a number of productive questions (e.g. open questions and probing questions) and unproductive questions (e.g. multiple questions and forced choice questions). It has been found that epistemicity is constructed in Mubarak's and Al-Adly's testimonies by employing a number of lexical and morphosyntactic markers to take up the Knowing, Unknowing and Believing positions. The analysis also shows that Mubarak and Al-Adly adopt the Knowing position more frequently than the Unknowing and the Believing positions when answering productive and unproductive questions. The frequency of occurrence of the Knowing position is higher when answering productive questions in the testimonies of both Mubarak and AlAdly.
\end{abstract}

Keywords: Epistemicity - storming prisons - Eastern borders Griffiths Question Map - the Knowing, Unknowing and Believing model. 


\title{
اتخاذ المواقف المعرفية في شهادة هبارك والعادلي في قضية اقتحام السجون
} والحدود الشرقية: التعبير عن مواقف المعرفة وعدم المعرفة والاعتقاد

\author{
د. - دروة هممد خميس \\ أستاذ مساعد- قسم اللفة الإنجليزية - كلية الاداب - جامعة الاسكندرية
}

\section{المغص العربي للدراسة}

يدرس البحث شهادة الرئيس الأسبق تحمد حسني مبارك ووزير الداخلية الأسبق حبيب

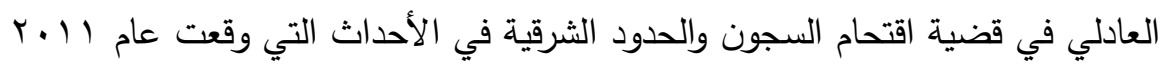

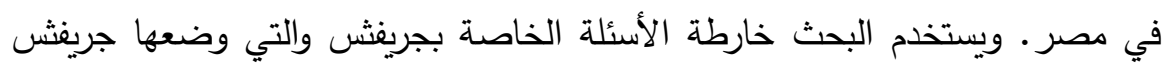

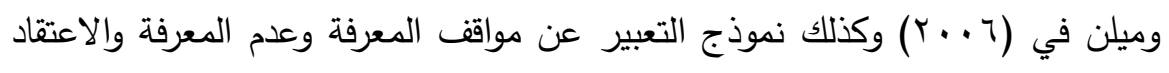

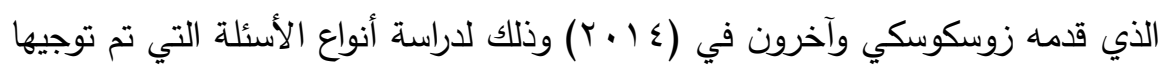
لمبارك والعادلي في القضية قيد البحث. كما يدرس البحث كيفية قيام مبارك والعادلي

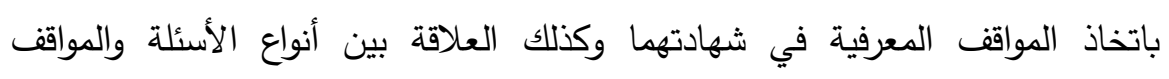

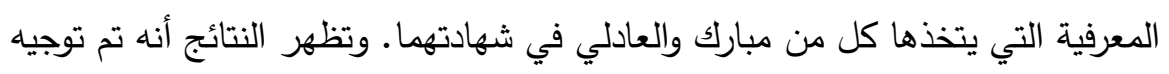

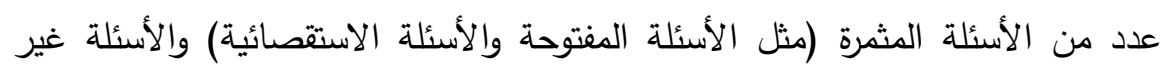

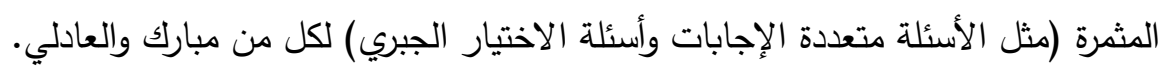

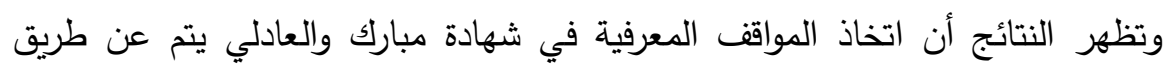

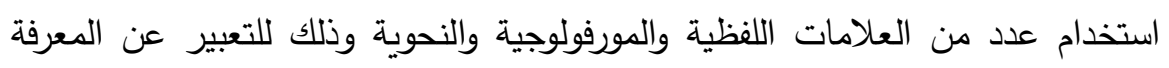

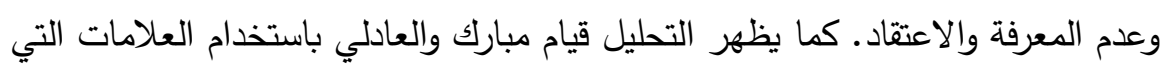

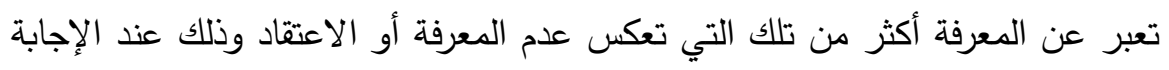

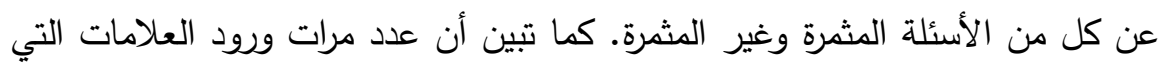
تعكس المعرفة في شهادة مبارك والعادلي أعلي في إجابات كلا الثاهدين علي الأسئلة المثمرة. الكلمات المفتاحية: اتخاذ المواقف المعرفية- اقتحام السجون - والحدود الشرقية- خارطة الأسئلة الخاصة بجريفش - نموذج التعبير عن مواقف المعرفة وعدم المعرفة والاعتقاد. 
Epistemicity in Mubarak's and Al-Adly's Testimonies in the "Storming

Prisons and Eastern Borders" case: The Knowing, Unknowing and Believing Positions

Dr. Marwa Mohamed Khamis

مجلة وادي النيل للاراسات والبحوث الإنسانية والاجتماعية والتريوية (مجلة علمية محكمة)

\section{Introduction}

The court is an important legal institution whose mission is to do justice in every case to make sure it is served to all those who need it because justice "represents the legal system used to achieve fair treatment of people, a medium to advocate the equality of all citizens before the law and the supremacy of the law above everyone" (Sanni, 2016, p. 1). Therefore, the language used in courtroom interaction differs from the one used in daily conversations, different speech events as well as different types of professional and institutional interaction. Indeed, language is an essential means in delivering justice in the judicial process, in general, and courtroom proceedings, in particular, since "laws, judgments, judicial proceedings are all conducted through language" (Sanni, 2016, p.1). In the courtroom, language is used by judges, prosecutors, attorneys, counsels and witnesses for various purposes such as examination, cross-examination, persuasion, conviction, acquittal, and eliciting information. Questioning witnesses is part and parcel of trials as their testimonies have an impact on the final verdicts. Therefore, the communication of knowledge on the part of witnesses and the degree of certainty (knowledge), uncertainty (belief) or neither certainty nor uncertainty (unknowledge) of information play an important role in shaping the judge's knowledge and the verdict reached. One important Egyptian court case in which the degree of knowledge, unknowledge or belief communicated in the witnesses' testimony was a central part of the trial is that of "storming prisons and Eastern borders". Two key witnesses in this case whose testimonies were broadcast and received wide attention are former President Mohamed Hosni Mubarak and former Minister of the Interior Habib Al-Adly. 
مجلة وادي النيل للاراسات والبحوث الإنسانية والاجتماعية والتربوية (مجلة علمية محكمة)

(ISSN : 2536 - 9555)

\section{Aims of the Study}

Language is the foundation stone of judicial institutions which practice law, including courts "in which not only what is said determines the verdict, but indeed also how it is said" (Mortensen \& Mortensen, 2017, p. 401). Participants in courtroom proceedings, including judges, attorneys and witnesses, employ language in the form of question-answer exchanges to gain thorough and detailed knowledge on the various cases examined and provide admissible evidence. Therefore, the types of questions asked and not only witnesses' testimonies but also their epistemicity, i.e. the degree of certainty displayed when making statements concerning having certain, uncertain or no knowledge about the case presented, play an essential role in the final ruling made. This is because the questions asked in trials give witnesses "a chance to tell their own stories, to build acceptability and thus persuade the jury of their version of facts" (Monsefi, 2012, p. 46). The different degrees of certainty and uncertainty are expressed using lexical and morphosyntactic markers. In this respect, the present study attempts to answer the following research questions:

1- What are the types of questions asked by the judge in the court case of storming Egypt's Eastern borders and springing key Muslim Brotherhood figures from prison?

2- How is epistemicity (epistemic stance) constructed in the testimony of Mubarak and Al-Adly?

3- What is the relation between the types of questions asked and the Knowing, Unknowing and Believing positions adopted by Mubarak and Al-Adly in their testimonies?

\section{Data and Methodology}

The testimonies of former President, Hosni Mubarak, and former Minister of the Interior, Habib Al-Adly, in the retrial of former President Mohamed Morsi and other key figures in the Muslim Brotherhood in the "storming prisons and Eastern borders" case constitute the data of the present study. It is considered one of

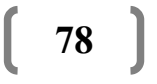




\section{Epistemicity in Mubarak's and Al-Adly's Testimonies in the "Storming Prisons and Eastern Borders" case: The Knowing, Unknowing and Believing Positions}

Dr. Marwa Mohamed Khamis

مجلة وادي النيل للاراسات والبحوث الإنسانية والاجتماعية والتريوية (مجلة علمية محكمة)

the most sensitive cases as it concerns Egypt's national security which has been endangered during the early days of the January $25^{\text {th }}$ Revolution when militants from the Gaza strip breached the country's Eastern border, infiltrated through the tunnels, attacked police headquarters, killed police and armed forces personnel, attacked jails, and freed Muslim Brotherhood figures from a number of prisons across the country. Mubarak's 90-minute testimony took place on Wednesday, December 26, 2018. AlAdly's testimony on October 28, 2018, which lasted for three hours, is analyzed in the present study. Videos of Mubarak's and Al-Adly's testimonies have been downloaded from YouTube and manually transcribed by the researcher. It is believed that the extreme importance and sensitive nature of the case have an effect on the Knowing, Unknowing and Believing epistemic positions taken by Mubarak and Al-Adly in their testimonies.

Two frameworks are employed in the study to examine the types of questions directed to Mubarak and Al-Adly as well as the epistemic positions adopted by each witness in his testimony. These are: the Griffiths Question Map (GQM) developed by Griffiths and Milne (2006) and the Knowing, Unknowing and Believing (KUB) model proposed by Zuczkowski et al. (2014). To analyze the data, the qualitative and quantitative approaches are used. In the qualitative analysis, illustrative examples of the different types of productive and unproductive questions as well as of the lexical and morphosyntactic markers of the Knowing, Unknowing and Believing positions are underlined and interpreted. The examples are translated into English but the analysis is carried out on the Arabic version since this is the mother tongue of both witnesses and the language used in the trial. In the quantitative analysis, the judge's questions are classified into the two categories given in the GQM, namely the productive and unproductive categories. The types of each of these categories which have been found in the data are manually counted. Similarly, the lexical and morphosyntactic markers of the Knowing, Unknowing and 
مجلة وادي النيل للاراسات والبحوث الإنسانية والاجتماعية والتربوية (مجلة علمية محكمة)

(ISSN : 2536 - 9555)

Believing positions employed in Mubarak's and Al-Adly's testimonies are manually counted. The frequency of occurrence of the types of productive and unproductive questions and the lexical and morphosyntactic markers of the Knowing, Unknowing and Believing positions in the data are tabulated, then differences in the frequency of occurrence of all the analyzed types of questions and markers of the three epistemic positions in Mubarak's and AlAdly's testimonies are interpreted.

\section{Theoretical Background}

\subsection{Forensic Linguistics}

Forensic linguistics is a growing area of applied linguistics that examines the interaction between language and judicial settings. It refers to "the interface between language, crime and law, where law includes law enforcement, judicial matters, legislation, disputes or proceedings in law" (Olsson, 2008, p. 3). Since law is considered a linguistic institution, in Forensic Linguistics, linguistic knowledge and methods are applied to forensic texts and contexts, including police investigations, crimes, civil legal processes, threatening letters, trials, authorship detection, judicial procedures, emails, text messages and suicide notes (Farinde, 2008; Monsefi, 2012; Oxburgh et al., 2016). Thus, Forensic Linguistics covers a wide range of topics ranging from legal language to plagiarism detection, and has a broad scope that includes, but is not limited to, Forensic Phonetics, Forensic Stylistics, Forensic Discourse Analysis and Courtroom Discourse (Coulthard \& Johnson, 2010; Sanni, 2016).

\subsection{Courtroom Discourse}

Since a court is a judicial institution where fair hearings and trials take place to promote justice, courtroom talk and interaction are essential components of the courtroom as an institutional context (Catoto, 2017; Monsefi, 2012; Sanni, 2016). Accordingly, courtroom discourse is primarily concerned with the analysis of the 
Epistemicity in Mubarak's and Al-Adly's Testimonies in the "Storming Prisons and Eastern Borders" case: The Knowing, Unknowing and Believing Positions

Dr. Marwa Mohamed Khamis

مجلة وادي النيل للاراسات والبحوث الإسانية والاجتماعية والتربوية (مجلة علمية محكمة)

language employed in courtroom proceedings which include "presentation of evidence, hearing testimonies of both parties, discourse between witnesses/defendants and interrogators, and the promulgation of decision" (Ceballos \& Sosas, 2018, p. 18).

In court proceedings, the focus is on the analysis of legal language as object, process and instrument. As an object, legal language highlights its tenacity due to the linguistic features and structures used in it. As a process, the interaction in which legal language is used and how it - legal language - establishes and maintains institutional power are analyzed. As an instrument, analysis of court proceedings shows how legal language is used to achieve social goals (Ceballos \& Sosas, 2018; Susanto, 2016; Stygall, 1994). Moreover, examining the legal language used in courtroom proceedings reflects how meaning is produced in the trial as well as how the use of language establishes power relations in the court (Ceballos \& Sosas, 2018; Mooney, 2014; Olsson, 2004; Stygall, 1994; Susanto, 2016). The act of questioning that takes place in court proceedings is the most distinctive linguistic feature that characterizes legal talk in various forensic settings such as police interviews, examination and cross-examination in court trials (Holt \& Johnson, 2010, p. 21).

\subsection{The Griffiths Question Map (GQM)}

In the Griffith's (2006) Question Map, the different types of questions are divided into two categories: productive and nonproductive. Productive questions are the proper way to obtain an appropriate account or data from interviewees concerning a case. They are divided into open questions, probing questions and appropriate closed yes/no questions. Open questions elicit full responses from witnesses who are obliged to provide truthful answers and accurate accounts of the events of the story relevant to the case. Examples of open questions include "Describe everything 
that happened in the shop?" and "Tell me about the argument with your wife?" Probing questions are intrusive and require giving specific answers with respect to the details of the case. They usually start with question words like "who", "what", "why", "where", "when", "which" or "how". These questions help obtain more details following a witness' initial account of the story. An example of probing questions is "You said you pushed your wife over, which part of her body hit the ground first" Appropriate closed yes/no questions such as "Did you strike the other man more than the one time you have described?" are used to conclude a topic, draw definite remarks, confirm or clarify a point and establish legal points after open and probing questions have been asked (Catoto, 2017; Griffiths \& Milne, 2006).

Unproductive questions are associated with poor questioning and include five types of questions. These are: the inappropriate closed yes/no questions, leading questions, multiple questions, forced choice questions, and opinion or statement. Inappropriate closed yes/no questions such as "Could you describe the man who pushed you?" allow witnesses to give undetailed answers and can decrease the range of responses available to witnesses. Leading questions make witnesses give an answer in formal content (e.g. "Are you normally that aggressive after drinking?"). Multiple questions include several sub-questions asked at once, thereby making it difficult to determine the one the witness is expected to answer. This is seen in "How did you get there, what did you do inside and when did you first decide to steal the car?" This type of questions can also include multiple concept questions in which the witness is asked about two concepts at once, as in "What did they look like?" Forced choice questions provide the witness a limited number of responses which affects the amount of information given on the case. This is shown in "Did you kick or punch the other woman?" In opinion or statement, rather than asking a question, opinions are given and statements put out to witnesses, as in "I think you did assault the other person" (Catoto, 2017; Griffiths \& Milne, 2006). 


\section{Epistemicity in Mubarak's and Al-Adly's Testimonies in the "Storming \\ Prisons and Eastern Borders" case: The Knowing, Unknowing and Believing Positions}

Dr. Marwa Mohamed Khamis

مجلة وادي النيل للاراسات والبحوث الإسانية والاجتماعية والتربوية (مجلة علمية محكمة)

\subsection{Epistemicity in Discourse}

Stance is an important aspect of daily communication in human discourse. Du Bois (2007) defines stancetaking as "a public act by a social actor, achieved dialogically through overt communicative means, of simultaneously evaluating objects, positioning subjects (self and others), and aligning with other subjects, with respect to any salient dimension of the sociocultural field" (p. 163). Wu (2004) holds that "stance is a speaker's indication of how he/she knows about, is commenting on, or is taking an effective or other position toward the person or matter being addressed" (p. 3). Stance also "refers to the particular viewpoint or enunciational position of the speaker/writer or of some other subject of conception, which reflects their attitudes, assessments and knowledge concerning the designated event and/or the communicated proposition" (Marin-Arrese, 2011, pp. 194-195). Stancetaking is further defined as "a form of social action, involving the expression of the speaker's/writer's personal attitudes, beliefs or assessments concerning events and their commitment with respect to the communicated proposition" (Marin-Arrese, 2013, p. 411). These definitions indicate that stance expresses a speaker's attitude and viewpoint towards an issue, his/her evaluation of a person or a matter, commitment to the content of a proposition, and display of knowledge with respect to an issue.

Stancetaking is of two types: effective stance and epistemic stance (epistemicity). The former refers to the speaker's/writer's assessment of a person, an issue or an event, and position regarding the necessity, desirability or possibility of the occurrence of events (Marin-Arrese, 2011, 2013; Tracy, 2011). Acts of effective stance aim "at determining or influencing the course of reality itself, and play a direct role in persuasion and in the legitimization of actions" (Marin-Arrese, 2013, p. 411). Epistemic stance, which is the focus

of the present study, refers to the speaker's/writer's display of 
مجلة وادي النيل للاراسات والبحوث الإنسانية والاجتماعية والتربوية (مجلة علمية محكمة)

(ISSN : 2536 - 9555)

certainty or doubt with respect to a proposition or state of affairs, and his/her commitment to the truth of the information provided (Keisanen, 2007; Marin-Arrese, 2015; Szczyrbak, 2018; Tracy, 2011). This is indicated by Marin-Arrese (2015) who holds that acts of epistemic stance

pertain to the positioning of the speaker/writer with respect to knowledge about described events and their commitment to the validity of the communicated information. They are characteristically aimed at the legitimization of the assertions, through the expression of speaker/writer's degree of certainty regarding the realization of the event and/or the reference to the sources and modes of access to that knowledge. (p. 211)

Accordingly, markers of epistemic stance indicate concern with the hearer's acceptance of the speaker's certainty or doubt regarding knowledge about events. They also signal evidence to prove the truth of a proposition, the source of information and perspective from which information is provided (Biber et al., 1999; MarinArrese, 2013).

\subsection{The Knowing, Unknowing and Believing Model}

The different degrees of certainty or uncertainty depend on the source of information and the way it was obtained, i.e. evidentiality. Information can be gained through perception (i.e. the five senses and proprioception) and cognition (i.e. memory, imagination, thought, etc.). For example, verbal expressions such as "I know", "I remember", "I see", "I think", "I imagine", "I believe" and "I suppose" are evidential markers as "opinions, beliefs, imagined scenarios, suppositions etc. are also considered to be modes of knowing and in this respect are sources of information" (Philip et al., 2013, p. 9).

In the KUB model, proposed by Zuczkowski et al. (2014), there are three evidential and epistemic categories of information that represent different stances speakers adopt to position 


\section{Epistemicity in Mubarak's and Al-Adly's Testimonies in the "Storming Prisons and Eastern Borders" case: The Knowing, Unknowing and Believing Positions}

Dr. Marwa Mohamed Khamis

مجلة وادي النيل للاراسات والبحوث الإنسانية والاجتماعية والتريوية (مجلة علمية محكمة)

themselves in relation to the information communicated in interaction. These are: the Known (certain), the Unknown (neither certain nor uncertain) and the Believed (uncertain).

The Known includes the information that speakers/writers communicate as certain based on evidentiality (i.e. what they perceive) or epistemicity (i.e. what they infer/deduct). For example, in "I see that Mary is on the beach", certainty is expressed through the evidential perceptual verb "I see", which is the source of information, and the declarative structure (Szczyrbak, 2018; Zuczkowski et al., 2014). Thus, the Knowing position refers to "all information that speakers/writers sat they 'Know' in the broadest sense (i.e. they perceive, remember, etc.)"(Philip et al., 2013 , p. 10). When a speaker/writer communicates a piece of information as Known (evidentiality), he/she is also communicating it as being certain (epistemicity). Similarly, information communicated as certain is also communicated as Known (Bongelli, 2012, 2013; Zuczkowski et al., 2014).

The Unknown refers to the information that speakers/writers communicate as neither certain nor uncertain because they lack it. The missing information has to be present since otherwise speakers/writers cannot communicate certainty or uncertainty. For example, in "I do not know where Mary is" and "Where is Mary?", the speaker/writer indicates lack of evidential knowledge of Mary's location. Thus, the absence of the source of information creates an informational gap that lacks epistemic commitment (Philip et al., 2013; Szczyrbak, 2018; Zuczkowski et al., 2014).

The Believed refers to information that expresses a speaker's/writer's beliefs, suppositions, opinions, doubts and assumptions. In other words, the Believing position comprises information that is communicated not as known but as probable, possible or uncertain, i.e. "information that speakers/writers say they do not know if or do not know whether" (Philip et al., 2013, p. 10). For example, in saying "I do not know if Alex is on the beach" 


\section{مجلة وادي النيل للاراسات والبحوث الإسانية والاجتماعية والتربوية (مجلة علمية محكمة)}

(ISSN : 2536 - 9555)

or "I think that Mary is on the beach", "I think", which is an evidential cognitive marker, indicates uncertainty as the speaker communicates knowledge about the possibility or likelihood of the situation but does not know if it is true. Thus, information that speakers/writers communicate as Believed is communicated as being uncertain and vice versa (Bongelli at al., 2012, 2013; Philip et al., 2013; Szczyrbak, 2018; Zuczkowski et al., 2014). The difference between the Believed (i.e. not knowing whether) and the Unknown (i.e. not knowing) is that absence or lack of knowledge characterizes all information communicated as Unknown. However, information that represents beliefs, doubts or suppositions is uncertain or unconfirmed (Philip et al., 2013, Zuczkowski et al., 2014).

To sum, information communicated as certain is communicated as something that is known to be true (the Known). Information communicated as uncertain is not known whether it is true or false (the Believed). Information communicated as neither certain or uncertain is communicated as unknown (the Unknown). (Bongelli et al., 2013; Zuczkowski et al., 2014).

\subsection{Markers of the Known, the Unknown and the Believed}

According to Zuczkowski et al. (2014) the Known/Certain, Unknown and the Believed/Uncertain are indicated in texts by employing a number of lexical and morphosyntactic markers. A summary of these markers is shown in Table (1) which is adopted from Zuczkowski et al. (2014, p. 129). 


\section{Epistemicity in Mubarak's and Al-Adly's Testimonies in the "Storming Prisons and Eastern Borders" case: The Knowing, Unknowing and Believing Positions}

Dr. Marwa Mohamed Khamis

مجلة وادي النيل للاراسات والبحوث الإنسانية والاجتماعية والتريوية (مجلة علمية محكمة)

Table (1): Lexical and morphosyntactic markers of the Known, the Unknown and the Believed

\begin{tabular}{|c|c|c|c|}
\hline Markers & Known & Unknown & Believed \\
\hline Lexical markers & 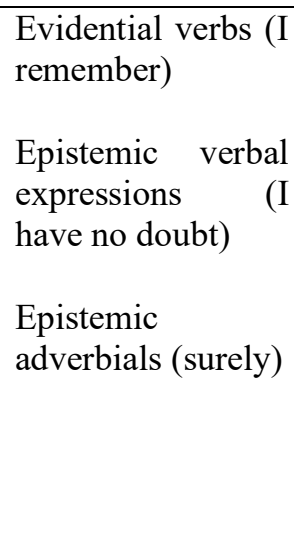 & $\begin{array}{l}\text { Negative form of } \\
\text { the evidential } \\
\text { verbs of the } \\
\text { Known (I don't } \\
\text { remember) } \\
\text { Adjectives }\end{array}$ & $\begin{array}{l}\text { Epistemic verbs } \\
\text { (I suppose) } \\
\text { Verbal epistemic } \\
\text { expressions (it is } \\
\text { possible) } \\
\text { Epistemic } \\
\text { adjectives and } \\
\text { adverbials } \\
\text { (likely, perhaps) } \\
\text { Modal verbs }\end{array}$ \\
\hline $\begin{array}{c}\text { Morphosyntactic } \\
\text { markers }\end{array}$ & $\begin{array}{llr}\text { Clauses } & \text { in the } \\
\text { present, past and } \\
\text { future } & \text { with no } \\
\text { lexical } & \text { evidential } \\
\text { or } & \text { epistemic } \\
\text { marker } & \end{array}$ & $\begin{array}{l}\text { 'Literal' } \\
\text { interrogatives } \\
\text { (i.e. excluding } \\
\text { rhetorical } \\
\text { questions, } \\
\text { question tags, } \\
\text { etc.) }\end{array}$ & $\begin{array}{l}\text { Modal verbs in } \\
\text { conditional and } \\
\text { subjunctive } \\
\text { moods } \\
\text { If clauses } \\
\text { Epistemic future }\end{array}$ \\
\hline
\end{tabular}

As shown in table (1), Known information (certainty) is indicated in texts by means of three groups of lexical markers. The first of these is evidential verbs in the first person singular or plural in the present simple tense (e.g. "I remember", "I know", "I see"), or in the third person singular or plural (e.g. "it tastes like", "it brings to mind", "it reminds me", "they recall me", "they remind me"). The second group comprises epistemic verbal expressions of certainty (e.g. "I am convinced", "I have no doubt", "I am sure"). The third group of lexical markers of the Known is epistemic adverbials such as "surely", "undoubtedly", and "certainly". Morphosyntactic 
markers that communicate Known information are present, past and future declarative sentences in the indicative mood even in the absence of epistemic or evidential markers as in "Alex was on the beach yesterday" and "Peter will be at home tomorrow" (Bongelli et al., 2012, 2013; Riccioni et al., 2013; Philip et al., 2013).

Lexically, the Unknown is expressed through the negation of the evidential verbs that indicate the Known when used in the affirmative (e.g. "I don't remember", "I don't know", "I don't see"). The negative forms of these verbs signal absence or lack of certainty rather than uncertainty (Believed). The same applies to adjectives whether they are with negative prefixes such as "The cause of the technical fault is unknown" or whose copular verb is used in the negative (e.g. "The cause of the glitch is not known"). Literal interrogatives are morphosyntactic markers of the Unknown as the interrogative pronouns "who...?", "where...?", "what...?", "when...?" and "how...?" signal that the speaker/writer has no information about an issue or a person (Philip et al., 2013; Szczyrbak, 2018; Zuczkowski et al., 2014).

The Believed (uncertainty) is communicated via some lexical and morphosyntactic markers. The former include epistemic verbs (e.g. "I suppose", "I assume", "I believe", "I doubt", "I/we think", "I imagine", "it seems to me"), verbal epistemic expressions (e.g. "it is probable", "it is possible", "I am not certain/uncertain", "I am not sure"), epistemic adjectives (e.g. "possible", "likely", "unlikely"), adverbs (e.g. "perhaps", "probably") and modal verbs such as "can", "could", "may", "might", "must", "would" and "should" when used epistemically. Three groups of morphosyntactic markers are used to communicate information. The first is modal verbs used in the conditional and subjunctive moods. The second group comprises conditional structures (i.e. If clauses) in which the Believed is expressed in the protasis and apodosis. The zero conditional is an exception as the present 
Epistemicity in Mubarak's and Al-Adly's Testimonies in the "Storming Prisons and Eastern Borders" case: The Knowing, Unknowing and Believing Positions

Dr. Marwa Mohamed Khamis

مجلة وادي النيل للاراسات والبحوث الإسانية والاجتماعية والتربوية (مجلة علمية محكمة)

simple is used in both the protasis and apodosis, and "if" is paraphrased by a temporal conjunction and does not communicate uncertainty. The last group is the epistemic future which refers to the conjectural use of "will" that can be paraphrased by other Believed (uncertainty) expressions. For example, in a plausible context, the phrase "He'll be at home now" when used to answer the question "where is Peter?" is considered an epistemic future as it can be paraphrased with "I think that Peter is at home" or "Perhaps Peter is at home" (Bongelli et al., 2012, 2013, 2019; Philip et al., 2013; Riccioni et al., 2013).

Previous research on courtroom discourse has mainly focused on different aspects of questioning and cross-examination (Biscetti, 2006; Catoto, 2017; Chang, 2004; Dong 2013; Eades, 2008; Gibbons, 2008; Hobbs, 2003; Monsefi, 2012; Sanni, 2016; Satia, 2013; Tkacukova, 2010; Villanueva \& Ranosa-Madrunio, 2016), argumentation in the courtroom (Jianmin, 2015; Mazzi, 2010; Toll \& Shi, 2019; Toska, 2012), court judgments (Cheng \& Cheng, 2014; Cheng \& Jiamin, 2018; Cruz \& Parina, 2015; Hernadez, 2017; Le et al., 2008; Ranosa-Madrunio, 2013; Moneva, 2013; Pei, 2015), and power in the court (Al-Gublan, 2015; Olanrewaju, 2010; Supardi, 2016; Tehseem \& Ali, 2015). Although some studies have been conducted on evidentiality and epistemic stancetakinng in courtroom discourse (Ibanez \& Kotwica, 2020; Mininni et al., 2014; Mortensen \& Mortensen, 2017; Szczyrbak, 2013, 2014, 2018) a few studies have examined epistemicity in witnesses' testimonies (Mortensen \& Mortensen, 2017; Szczyrbak, 2018). Given the scant academic attention that epistemic stancetaking in the courtroom discourse has received, the presents study attempts to fill this gap in the literature by examining epistemicity in the testimony of former President Hosni 


\section{مجلة وادي النيل للاراسات والبحوث الإنسانية والاجتماعية والتربوية (مجلة علمية محكمة)}

(ISSN : 2536 - 9555)

Mubarak and former Minister of the Interior Habib Al-Adly in the legal case of breaching Egypt's Eastern borders and breaking jails. To the researcher's knowledge, no studies have examined epistemic stance in the testimonies of Arabic-speaking witnesses in general or Arab politicians during or following the Arab spring in particular.

\section{Analysis}

In this section, the different types of questions employed by the judge in the "storming prisons and Eastern borders" case are presented and analyzed. It also analyses the epistemic stances adopted by Mubarak and Al-Adly in their testimonies by presenting the lexical and morphosyntactic markers employed by each witness to communicate Knowing (certain), Unknowing (neither certain nor uncertain) and Believing (uncertain) information concerning the case.

\subsection{Types of Questions}

The two main types of questions proposed by Griffiths and Milne (2006) in the GQM, namely the productive and unproductive questions, have been found in the data. As for the sub-types of productive questions, open questions are asked to Al-Adly only whereas probing questions and appropriate closed yes/no questions are asked to both Mubarak and Al-Adly. Extract (1) demonstrates an open question addressed to Al-Adly.

\section{Extract (1)}

القاضي: هل كان تسلل بعض العناصر الأجنبية من الحدود الثرقية نفاذا لما اتفق عليه

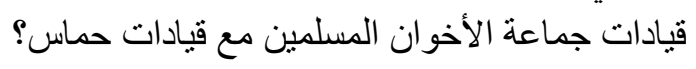

(Judge: Was the infiltration of some foreign elements through the Eastern borders an implementation of the agreement between MB leaders and those of Hamas?) 
Epistemicity in Mubarak's and Al-Adly's Testimonies in the "Storming

Prisons and Eastern Borders" case: The Knowing, Unknowing and Believing Positions

Dr. Marwa Mohamed Khamis

مجلة وادي النيل للاراسات والبحوث الإنسانية والاجتماعية والتريوية (مجلة علمية محكمة)

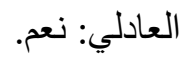

(Al-Adly: Yes.)

القاضي: وكيف تأكدت من ذلك؟

(Judge: How did you make sure?)

العادلي: الأحداث كلها متر ابطة مع بعض.

(Al-Adly: All events are interrelated.)

(Judge: Explain to us.)

القاضي: وضح لنا حضرتك

(Sada El-balad, 2018b)

In this example, when Al-Adly affirms that some foreign elements infiltrated the Eastern borders to implement what has been agreed upon between leaders of the Muslim Brotherhood and those of Hamas, and justifies his assurance by saying الأحداث كلها "مترابطة مع بعض" (All events are interrelated), the judge asks an open question, namely "وضح لنا حضرتك "(Explain to us) to urge AlAdly to elaborate and give a longer and more detailed answer to the previous question "وكيف تأكدت من نلك؟ (How did you make sure?), thereby giving more precise information and details to prove what he says.

Extracts (2) and (3) present probing questions asked to Mubarak and Al-Adly, respectively.

\section{Extract (2)}

القاضي: هل تسنطيع تحديد السجون التي قاموا بمهاجمتها للإفراج عن المسجونين حسبما قررت؟

(Judge: Can you determine the prisons they attacked to release prisoners, as you state?)

$$
\text { مبارك: وادي النطرون أساسا. }
$$

(Mubarak: Mainly Wadi Al-Natroun prison.) 
(ISSN : 2536 - 9555)

$$
\text { القاضي: و ادي النطرون أساسا. لِيه و ادي النطرون؟ }
$$

(Judge: Mainly Wadi Al-Natroun prison. Why Wadi Al-Natroun?)

(Sada El-balad, 2018a)

In extract (2), when Mubarak is asked to name the prisons that were attacked to release prisoners, he says "وادي النطرون أساسا" (Mainly Wadi Al-Natroun). Focusing on this particular prison although the judge wanted to know all other prisons that were attacked drives him - the judge - to ask the probing question ليه (Why Wadi Al-Natroun?) to make the witness provide reasons for his answer and explain the infiltrators' concern with this prison in particular.

\section{$\underline{\text { Extract (3) }}$}

$$
\text { القاضي: أين كانت تتم تلك اللقاءات ومتي كان ذللك تحديدا؟ }
$$

(Judge: Where were the meetings held, and when was that exactly?)

$$
\begin{aligned}
& \text { العادلي: لا أنذكر طبعا، كانت بتعقد في بيروت. اللقاءين اللي حصلو ا مع قيادات الأخوان } \\
& \text { مع حماس كانوا في بيروت، ومش منذكر التاريخ بالظبط. }
\end{aligned}
$$

(Al-Adly: I don't remember, of course. They were held in Beirut. The two meetings that took place between MB leaders and Hamas were held in Beirut. I don't remember the exact date.)

$$
\text { القاضي: ما هو محور الحديث في تلك اللقاءات؟ }
$$

(Judge: What was the focus of these meetings?)

(Sada El-balad, 2018b)

In this extract, AL-Adly is required to provide information about the meetings that were held between MB leaders and Hamas. After saying where the meetings took place, Al-Adly is asked a probing question "ما هو محور الحديث في تلك اللقاءات؟ (What was the focus of these meetings) so as to give detailed information about 
Epistemicity in Mubarak's and Al-Adly's Testimonies in the "Storming

Prisons and Eastern Borders" case: The Knowing, Unknowing and Believing Positions

Dr. Marwa Mohamed Khamis

مجلة وادي النيل للاراسات والبحوث الإسانية والاجتماعية والتربوية (مجلة علمية محكمة)

what went on in these meetings and what the parties involved in them agreed upon.

Mubarak and Al-Adly were also asked appropriate closed yes/no questions that aim to establish legal points as the witnesses clarify their answers based on the content of the questions. This is shown in extracts (4) and (5).

\section{Extract (4)}

و الحركة الفلسطينية الاتفاق بمعت جماعة الأخوان المسلمين مع العناصر الأخرب من حماس

(Judge: Have you heard of the agreement between the Muslim Brotherhood and elements from Hamas and the Palestinian Movement?)

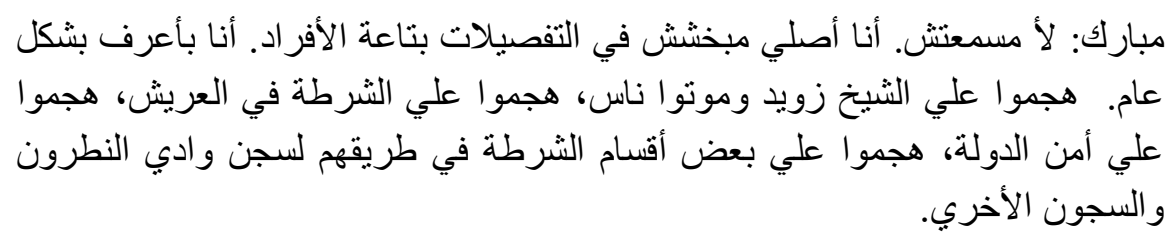

(Mubarak: No, I haven't heard about it. I don't get into details concerning individuals. I know things in general. They attacked Sheikh Zowaid and killed people. They attacked the police in AlArish, the State Security Office and some police stations on their way to Wadi Al-Natroun prison and the other prisons.)

(Sada El-balad, 2018a)

In extract (4), the judge asks Mubarak a closed yes/no question to know whether he heard about the agreement between the Muslim Brotherhood and elements from Hamas and the Palestinian Movement. Although the question is answerable by either yes or no only, Mubarak, in addition to denying knowing 
about the agreement saying "لأ مسمعتش" (No, I haven't heard about it), provides extra information that is related to the question, though not included in it, to clarify what he knows about the deeds perpetrated by the parties that the judge asks about, namely Hamas and the Muslim Brotherhood.

\section{Extract (5)}

$$
\begin{aligned}
& \text { العادلي: بداية التدمير اللي حصل في العريش حصل في مبني أمن الدولة، حصل لنقطة }
\end{aligned}
$$

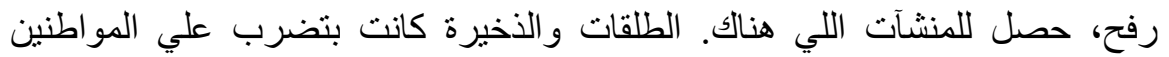

$$
\begin{aligned}
& \text { و الأفر اد بعدد ضخم جدا. }
\end{aligned}
$$

(Al-Adly: The devastation in Al-Arish first happened in the State Security Office, Rafah checkpoint and the establishments there. Citizens and personnel were heavily shot.)

(Judge: Did this result in deaths?)

$$
\text { القاضي: أسفر عن قتلى؟ }
$$

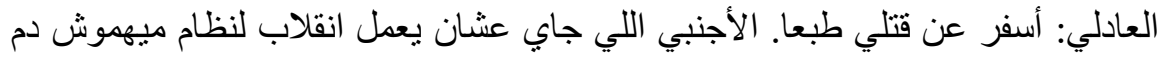

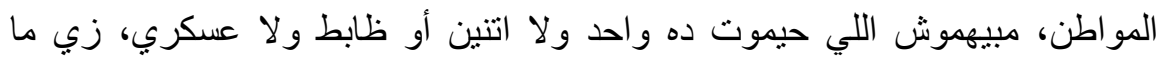

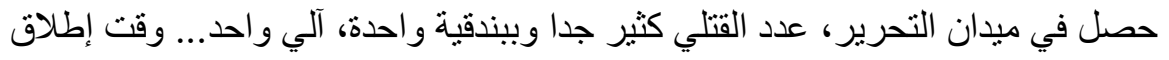

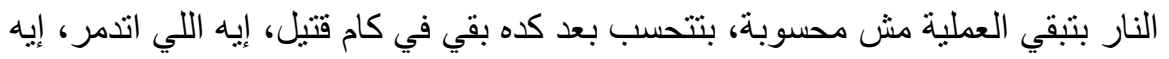

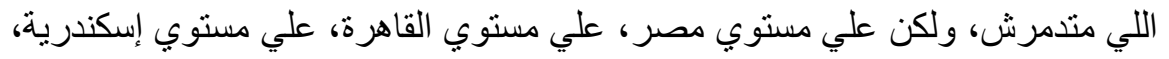
علي مستوي اللي حصل في العريش وفي مناطق أخري كان دمار بمعني دمار. (Al-Adly: Of course it resulted in deaths. A foreigner who comes to overthrow a regime doesn't care about the citizen's life. He doesn't care how many will die or whether this person is an officer or a soldier. This is what happened in Tahrir square. There were so many deaths and one gun or weapon. At the time of shooting, nothing is calculated. This happens afterwards when we start to know the number of deaths and what was or was not destroyed. What happened all over Egypt, whether in Cairo, Alexandria, AlArish or other places, was destruction in every sense of the word.)

(Sada El-balad, 2018b) 
Epistemicity in Mubarak's and Al-Adly's Testimonies in the "Storming Prisons and Eastern Borders" case: The Knowing, Unknowing and Believing Positions

Dr. Marwa Mohamed Khamis

مجلة وادي النيل للاراسات والبحوث الإنسانية والاجتماعية والتريوية (مجلة علمية محكمة)

In this extract, Al-Adly talks about the devastation that happened in Al-Arish. When he says that the State Security Office, Rafah checkpoint and other establishments were destroyed and citizens and personnel were shot, the judge asks him a closed yes/no question which is "أسفر عن قتلي؟" (Did this result in deaths?). Rather than merely confirming the presence of deaths, Al-Adly explains the reason for the presence of a large number of deaths. Although the judge's question requires yes or no as an answer with no further explanation, Al-Adly deems it necessary not to say that the acts committed in Al-Arish resulted in deaths but also to make use of the context of the question to relate what happened in AlArish to the destruction that swept through Egypt.

As for unproductive questions, it has been found that inappropriate closed yes/no questions and multiple questions are addressed to both Mubarak and Al-Adly. Leading questions are asked to Mubarak only whereas forced choice questions are addressed only to Al-Adly. No personal opinions or statements are put either to Mubarak or Al-Adly instead of asking questions. In answering inappropriate closed yes/no questions, both Mubarak and Al-Adly give evasive answers, as shown in extracts (6) and (7).

\section{Extract (6)}

القاضي: هل تستطبع تحديد أشخاص بعينهم مسئولين عن هذا التسلل أو مدن تسللو إلبي

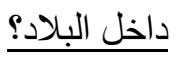
(Judge: Can you specify the ones responsible for the infiltration or who actually infiltrated into the country?) 
مجلة وادي النيل للاراسات والبحوث الإنسانية والاجتماعية والتربوية (مجلة علمية محكمة)

(ISSN : 2536 - 9555)

بيسارك: هم تسللوا...تنلل يعني دخل خلسة أو دخل النفق وطلع و اتوزعوا وقابلهم ناس

(Mubarak: They infiltrated. To infiltrate means to sneak or enter the tunnel and come out. They spread and met people who facilitated the process.)

القاضي: من هؤ لاء الأشخاص الذين قاموا بتسهيل تسللهم إلي داخل البلاد؟ (Judge: Who are the ones who facilitated their infiltration into the country?)

$$
\text { مبارك: ناس من شمال سيناء معرفش هو يتهم إيه. }
$$

(Mubarak: People from North Sinai. I don't know their identity.)

(Sada El-balad, 2018a)

In this extract, when the judge asks Mubarak if he can tell who was responsible for the infiltration of foreign elements into the country or who actually infiltrated, Mubarak does not give an answer. Rather, he explains what "to infiltrate" means saying تسلل (To infiltrate...out) and says that when the intruders crossed the borders, they went to different places and met people who facilitated this process. Because Mubarak's reply is evasive as he does not say who helped foreign elements cross the borders, the judge repeats his question, saying "من هؤلاء...البلاد؟") Who are the ones...country?) to elicit a direct answer and he succeeds in doing so as Mubarak answers directly saying "ناس من شمال سيناء... (People from North Sinai...).

\section{Extract (7)}

القاضي: هل تمكنت تلك العناصر من السيطرة علي المعابر الحدودية بعد تسللهم عبر

الحدود الثرقية: هلئب

(Judge: Did these elements manage to take control of the border crossing points after they infiltrated across the eastern borders?) 


\section{Epistemicity in Mubarak's and Al-Adly's Testimonies in the "Storming Prisons and Eastern Borders" case: The Knowing, Unknowing and Believing Positions}

Dr. Marwa Mohamed Khamis

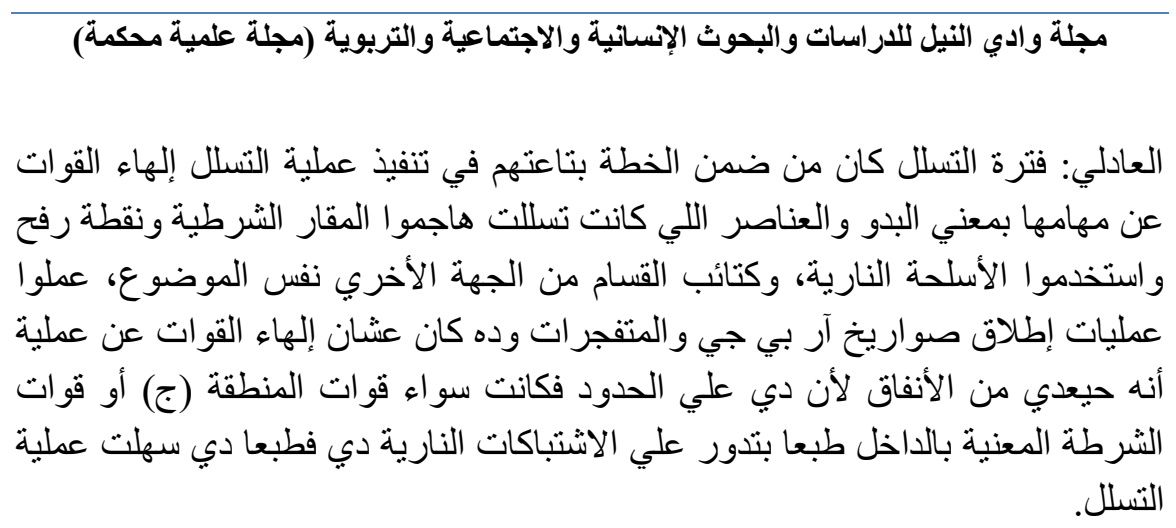

(Al-Adly: Part of the plan to infiltrate was to distract the forces. I mean, the Bedouins and the elements who infiltrated attacked the police stations and Rafah checkpoint, and used gun weapons. AlQassam Brigades, on the other side, did the same thing. They used RPGs and explosives to distract the forces so as not to know that these elements will infiltrate through the cross-border tunnels. Border Guard Forces in Area (C) and interior police forces were involved in these fire fights. Of course, this facilitated the infiltration of these elements.)

$$
\text { القاضي: أيوة اتحقق لهم السيطرة و لا متحققش؟ }
$$

(Judge: Yes but did they take control of the border crossing points or not?)

العادلي: اتحقق لهم طبعا السيطرة.

(Al-Adly: Of course they took control of these points).

(Sada El-balad, 2018b)

In extract (7), Al-Adly is asked about whether the foreign elements that infiltrated across the borders managed to dominate the border crossing points. Instead of providing a direct answer, he evades the closed yes/no question by giving detailed, albeit unrequired, information concerning how these succeeded in illegally crossing the borders. Because this evasive reply does not 
مجلة وادي النيل للاراسات والبحوث الإنسانية والاجتماعية والتربوية (مجلة علمية محكمة)

(ISSN : 2536 - 9555)

answer the judge's question, he repeats the question again and asks for a specific and direct answer which Al-Adly provides, saying "اتحقق لهم السيطرة طبعا" (Of course, they took control of these points).

Multiple questions are shown in extracts (8) and (9).

\section{Extract (8)}

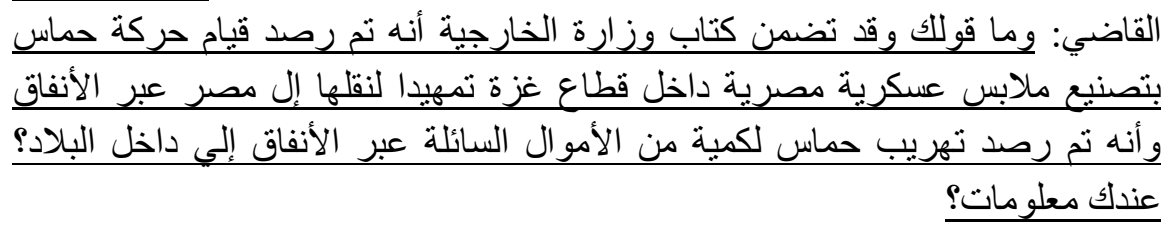

(Judge: What do you think of what the Ministry of Foreign Affairs stated, namely that Hamas made Egyptian military clothes in Gaza to take them to Egypt through the tunnels, and that Hamas has smuggled liquid money through the tunnels into the country? Do you have any information?)

(Mubarak: No, I don't.)

$$
\text { مبارك: ل أ معنديش. }
$$

(Sada El-balad, 2018a)

In extract (8), the judge tells Mubarak about two actions carried out by Hamas in relation to the tunnels, namely making fake Egyptian military clothes in Gaza to take them to Egypt through the tunnels, and smuggling liquid money into Egypt through the tunnels as well. The judge asks Mubarak a couple of questions, one concerning his opinion of what the Ministry of Foreign Affairs stated with respect to what Hamas did. The other question is about whether he has any information regarding the issue. These multiple questions are unproductive for two reasons, the first of which is that they make it difficult for the witness to know which question he is supposed to answer. The second reason is that they allow the witness to avoid providing an answer. This is 
Epistemicity in Mubarak's and Al-Adly's Testimonies in the "Storming

Prisons and Eastern Borders" case: The Knowing, Unknowing and Believing Positions

Dr. Marwa Mohamed Khamis

مجلة وادي النيل للاراسات والبحوث الإنسانية والاجتماعية والتريوية (مجلة علمية محكمة)

evident in Mubarak's response as he does not answer the first question and denies knowing anything when asked about any information he might have concerning the matter.

\section{Extract (9)}

القاضي: هل استخدمو اتلك الاسلحة في مو اجهة رجال الثرطة بعد تسلالهم من الأنفاق؟ و هل لايك علم حول قيامهم بتفجير الأكمنة وخطوط الغاز في ذلك الوقت؟

(Judge: Did they use these weapons to attack policemen after infiltrating through the tunnels? Do you know whether they attacked ambushes and blew up gas pipelines at that time?)

العادلي: عن آخر حاجة خطوط الغاز - خطوط الغاز كانت فعلا بيحصل فيها تفجيرات

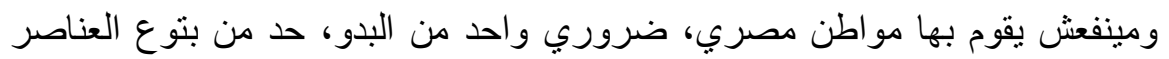

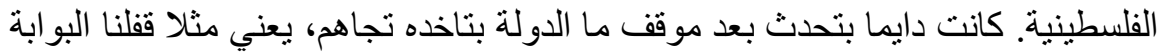

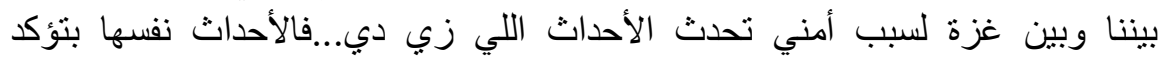
المعلومات دي. (Al-Adly: Concerning the last point, it is true that gas pipelines were blown up. It's not possible that an Egyptian does this. It must be a Bedouin or a Palestinian. It always happened following an action taken by the State like closing the Rafah crossing with Gaza for security reasons. Events themselves confirm this information)

(Sada El-balad, 2018a)

In this extract, the judge asks Al-Adly two questions at once, one of which has to do with whether the foreign elements attacked policemen after they infiltrated through the tunnels. The second is about whether AL-Adly knows if they attacked police ambushes and blew up gas pipelines. The fact that Al-Adly makes it clear that he will answer the part related to the gas pipelines only 
indicates that these multiple questions are unproductive as they limit the scope of answers that a witness can provide.

Extract (10) is an example of leading questions which are addressed only to Mubarak.

\section{Extract (10)}

القاضي: اللواء ماجد نوح قائد قوات الأمن المركزي بسيناء شهر أمام المحكمة بأن

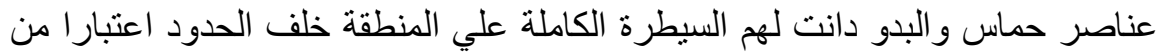

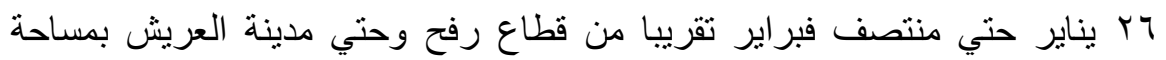

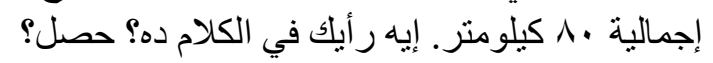

(Judge: Major General Maged Noah, Leader of Central Security Forces in Sinai, testified that elements from Hamas and the Bedouins almost fully controlled 80 kilometers of the area behind the borders from Rafah to Al-Arish from January 26 to mid February. What do you think? Did this happen?)

$$
\text { مبارك: مقدرش أقطع به. }
$$

(Mubarak: I can't confirm.)

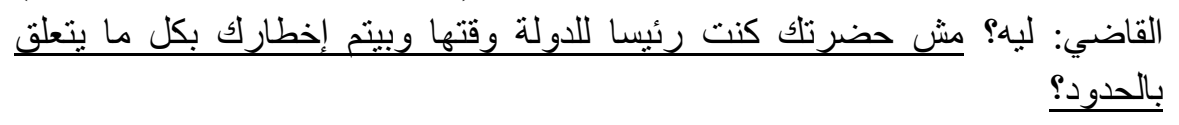

(Judge: Why? Weren't you a president at that time and were supposedly notified of everything related to the borders?)

(Sada El-balad, 2018a)

In extract (10), the judge asks Mubarak about his take on some information that was given by Major General Maged Nooh, Leader of the Central Security Forces in Sinai, before the court concerning Hamas and the Bedouins' control of 80 kilometers of the area behind the border from Rafah to Al-Arish. When Mubarak says that he cannot confirm this information, the judge asks the leading question "مش حضرتك ...بالحدود؟" (Weren't you...borders?) that indicates suggestibility so as to try to elicit the expected 
Epistemicity in Mubarak's and Al-Adly's Testimonies in the "Storming

Prisons and Eastern Borders" case: The Knowing, Unknowing and Believing Positions

Dr. Marwa Mohamed Khamis

مجلة وادي النيل للاراسات والبحوث الإنسانية والاجتماعية والتريوية (مجلة علمية محكمة)

affirmative answer, namely that Mubarak, as President, used to receive information regarding the borders.

An example for forced choice questions, which were asked to Al-Adly only, is given in extract (11).

\section{Extract (11)}

القاضي: كيف تمكنت العناصر التي تسللت عبر الحدود الثرقية من الوصول إلي

السجون و اقتحامها؟ و هل كان ذللك بمساعدة من قيادات جماعة الأخو ان؟

(Judge: How did the elements who infiltrated through the Eastern borders manage to get to the prisons and break into them? Did this happen with the help of MB leaders?)

العادلي: التنسيق وفق الخطة.

(Al-Adly: The coordination took place according to the plan.)

القاضي: خطة سابقة ولا خطة؟

(Judge: A plan which was prepared beforehand or an immediate one?)

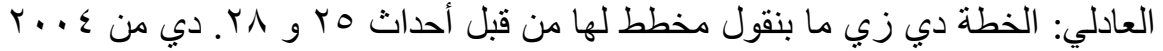

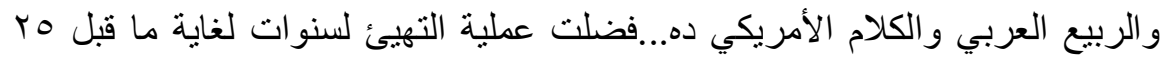

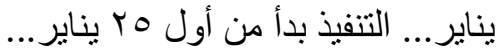

(Al-Adly: This plan, as we say, was devised prior to the events that took place on January 25 and 28. It was formulated since 2004, the Arab Spring and all this American talk...The arrangement process lasted for so long until the period preceding January 25. The implementation started on January 25.)

(Sada El-balad, 2018b)

In this extract, when Al-Adly says "التنسيق وفق الخطة" (The coordination took place according to the plan) in answer to the judge's question about how the foreign elements that infiltrated 


\section{مجلة وادي النيل للاراسات والبحوث الإنسانية والاجتماعية والتربوية (مجلة علمية محكمة)}

(ISSN : 2536 - 9555)

through the tunnels managed to break into the prisons, and whether they were helped by MB leaders, the judge asks the forced choice question (A plan which was prepared beforehand or an immediate one?) to seek clarification about whether Al-Adly talks about a plan that was previously prepared or one that they plotted on the spot. Al-Adly's response, in which he states that it was an old plan, indicates that forced choice questions provide witnesses with a restricted number of replies.

\subsection{The Knowing Position in Mubarak's and Al-Adly's Testimonies}

In their testimonies, Mubarak and Al-Adly employ a number of lexical and morphosyntactic markers to communicate their knowledge and certitude about certain pieces of information conveyed in their responses to the judge's questions. In terms of the lexical markers of the Knowing position, the data shows that evidential verbs and epistemic adverbials occur in Mubarak's and Al-Adly's responses whereas epistemic verbal expressions of certainty are not employed by either witness. Extract (12) demonstrates the use of the evidential verb "I know" in Mubarak's answer to a question about the tunnels.

\section{Extract (12)}

$$
\text { القاضي: هل عندك معلومات إن كان في أنفاق موجودة علي الحدود الثرقية للبلاد؟ }
$$

(Judge: Do you know about the presence of tunnels on the Eastern borders of the country?)

$$
\text { مبارك: عندي هذه المعلومات لكن ما قبلها فيه حساسية للأمن القومي }
$$

(Mubarak: I know this information but what happened before that is sensitive to the national security.)

(Sada El-balad, 2018a) 
Epistemicity in Mubarak's and Al-Adly's Testimonies in the "Storming

Prisons and Eastern Borders" case: The Knowing, Unknowing and Believing Positions

Dr. Marwa Mohamed Khamis

مجلة وادي النيل للاراسات والبحوث الإنسانية والاجتماعية والتريوية (مجلة علمية محكمة)

In this extract, the judge wants to know whether Mubarak knows about the presence of tunnels on Egypt's Eastern borders. When he asks Mubarak about this matter, he replies saying عندي" هذه المعلومات (I know this information). The evidential verb "I know" is employed to convey a high degree of certainty about the truth of the information Mubarak has regarding this issue.

The use of the evidential verb "say" in Al-Adly's testimony is shown in extract (13).

\section{$\underline{\text { Extract (13) }}$}

$$
\text { القاضي: اتحقق لهم السيطرة ولا متحققش؟ }
$$

(Judge: Did they succeed in controlling the border crossing points or not?)

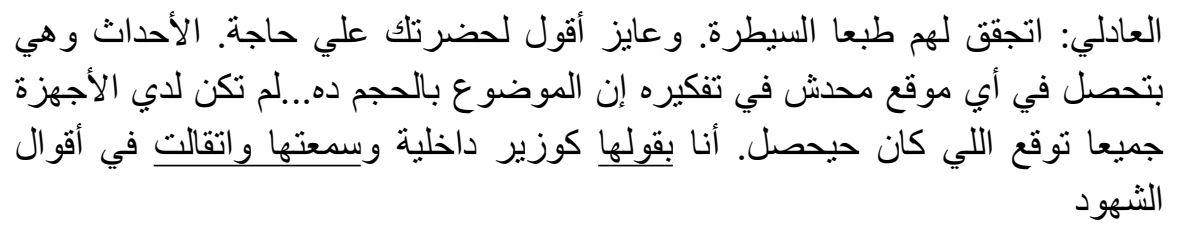

(Al-Adly: Of course they did. I want to tell you something, your honor. Nobody could have imagined the consequences of the events that happened. All state agencies did not expect what happened. I say this as a Minister of the Interior, I also heard it and it was mentioned in witnesses' testimonies).

(Sada El-balad, 2018b)

In this extract, the judge wants to know whether the infiltrators who illegally crossed the Eastern borders succeeded in taking control of the border crossing points. Al-Adly asserts that they managed to control these points. He also adds that the massive 


\section{مجلة وادي النيل للاراسات والبحوث الإنسانية والاجتماعية والتربوية (مجلة علمية محكمة)}

(ISSN : 2536 - 9555)

consequences of the 2011 events were not expected. To communicate certainty and emphasize the truth of what he says, Al-Adly uses the evidential verbs "بقولهاتها" (I say this), (heard it) and "انقالت" (it was mentioned).

The use of epistemic adverbials in Mubarak's and Al-Adly's responses is shown in extracts (14) and (15)

\section{Extract (14)}

القاضي: هل ارتكب هؤلاء الأشخاص أية أفعال تؤدي إلي المساس بسلامة البلاد وحريتها واستقلال أراضيها؟

(Judge: Have these people carried out any deeds that could jeopardize its security, freedom and autonomy?)

$$
\text { مبارك: قطعا، بالقطع ال . . 1 واحد دول في مساس بأمن البلاد. }
$$

(Mubarak: Definitely. These 800 persons surely jeopardized the security of the country.)

(Sada El-balad, 2018a)

In extract (14), the judge asks Mubarak about whether the foreign elements that illegally crossed the tunnels committed actions that could undermine Egypt's security, freedom and autonomy. In his reply, Mubarak uses the two epistemic adverbials "بطعا" (curely) to communicate absolute certitude and ascertain the truth of the proposition.

\section{Extract (15)}

القاضي: هل وققت علي شخصية أي من هذه العناصر البدوية أو العناصر التابعة لحماس أو حزب الثثرة الإيراني؟ (Judge: Did you manage to identify any of these Bedouins or the elements affiliated to Hamas or the Iranian Revolutionary Guard Corp?) 
Epistemicity in Mubarak's and Al-Adly's Testimonies in the "Storming Prisons and Eastern Borders" case: The Knowing, Unknowing and Believing Positions

Dr. Marwa Mohamed Khamis

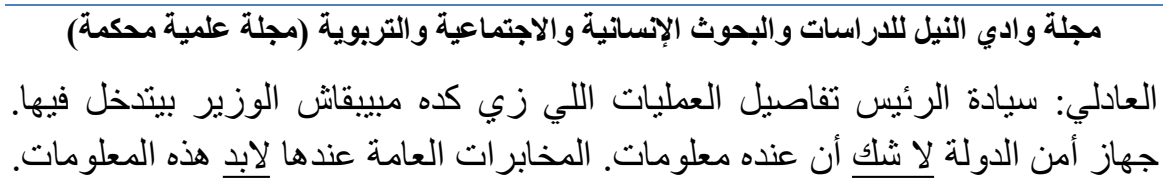

(Al-Adly: Your honor, the minister doesn't interfere in these details. The State Security Service undoubtedly has information. The General Intelligence Service surely has this information.)

(Sada El-balad, 2018b)

In this extract, Al-Adly is asked whether he could identify any of the Bedouins who helped infiltrators cross the borders or the elements affiliated to Hamas or IRSC. Because AL-Adly does not know the required information, he tells the judge that he, as a minister, does not know details as there are other entities that have all the details. To emphasize his knowledge and certainty about "لا شك" what he says, he uses the two epistemic adverbials (undoubtedly) and "لابد" (surely).

The data reveals that one more epistemic lexical marker, which is not given in the KUB model, is employed in Mubarak's and Al-Adly's testimonies, namely reference to shared epistemic background knowledge. This is shown in extracts (16) and (17).

\section{$\underline{\text { Extract (16) }}$}

القاضي: هل أخبرك بهوية أي من هؤلاء المتسللين؟ (Judge: Has he told you about the identity of any of these infiltrators?)

$$
\text { مبارك: لأ لأ ماقليش حاجة عن هو يتهم. لكن معروف هم جايين منين. }
$$

(Mubarak: No, no. He told me nothing about their identities but it's known where they came from.)

(Sada El-balad, 2018a) 
(ISSN : 2536 - 9555)

In extract (16), Mubarak is asked whether former Intelligence Chief told him about the identity of the elements that illegally crossed the tunnels. Mubarak denies being told about their identities and relies on common knowledge not only of the events that took place in 2011 but also of the fact that everybody knows that intruders crossed the tunnels from Gaza to Egypt to allude to their identities. Reference to shared common knowledge is shown in the use of "معروف" (It's known).

\section{Extract (17)}

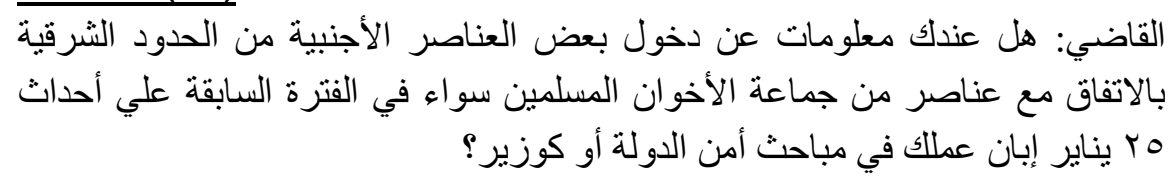

(Judge: Do you have information about the infiltration of foreign elements through the Eastern borders in agreement with the Muslim Brotherhood prior to the January 25 events following your work in the State Security Service or as a minister?)

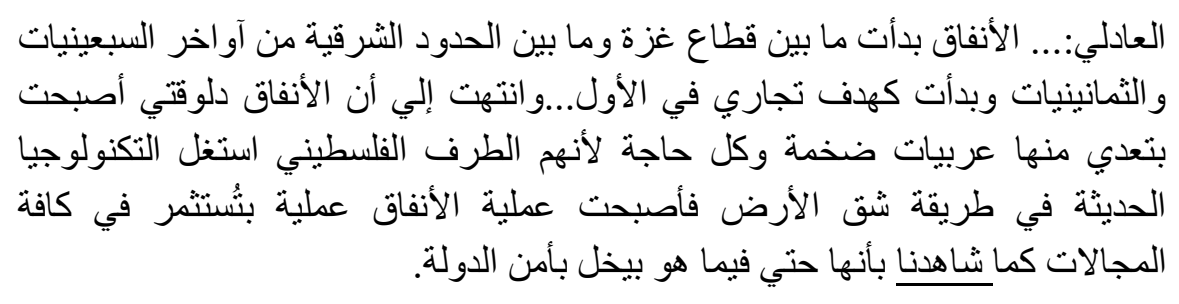

(Al-Adly: The tunnels between Gaza and the Eastern borders started in the late $70 \mathrm{~s}$ and $80 \mathrm{~s}$. At first, they were used for communicative purposes but then huge cars and all sorts of things were transported through the tunnels because the Palestinian side made use of modern technology to dig the tunnels so they came to be used for all purposes including, as we saw, carrying out deeds that endanger state security.)

(Sada El-balad, 2018b) 


\section{Epistemicity in Mubarak's and Al-Adly's Testimonies in the "Storming Prisons and Eastern Borders" case: The Knowing, Unknowing and Believing Positions}

Dr. Marwa Mohamed Khamis

مجلة وادي النيل للاراسات والبحوث الإسانية والاجتماعية والتربوية (مجلة علمية محكمة)

In extract (17), Al-Adly is asked about what he knows regarding an agreement between foreign elements and the Muslim Brotherhood to cross from Gaza to Egypt's Eastern borders through the tunnels. To answer the question, Al-Adly starts by providing information about the history of the tunnels, when they started, why they were used and how they developed. He says that Palestinians employed modern technology to develop various uses of the tunnels, some of which are harmful. Al-Adly resorts to shared background knowledge by saying كما شاهدنا بأنها حتي فيما هو (including, as we saw, carrying out deeds that endanger state security) to remind hearers of the unpleasant events that took place in 2011 in Egypt which everybody is familiar with. By referring to common knowledge, Al-Adly aims to gain support and approval of his proposition that the tunnels were used for harmful purposes such as jeopardizing state security.

Declarative sentences that lack lexical evidential or epistemic markers are the morphosyntactic markers employed in the data to communicate the Knowing position. These are shown in extracts (18) and (19).

\section{$\underline{\text { Extract (18) }}$}

$$
\text { القاضي: ولماذا انتثرو ا في تلك الأماكن؟ }
$$

(Judge: Why have they gone to these places?)

مبارك: في السجون عثان يخرّجوا المسجونين الموجودين من حزب الله ومن حماس ومن الأخو ان المسلمين

(Mubarak: They went to prisons to release prisoners belonging to Hezbollah, Hamas and the Muslim Brotherhood

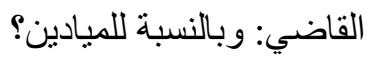

(Judge: What about the squares?) 
مجلة وادي النيل للاراسات والبحوث الإنسانية والاجتماعية والتريوية (مجلة علمية محكمة)

(ISSN : 2536 - 9555)

مبارك: في الميادين كانوا بيضربوا نار من فوق في الميادين. بيطلعو ا في العمارات

ويضربو انار.

(Mubarak: In the squares, they shot fires from above. They climbed up buildings and shot fire.)

(Sada El-balad, 2018a)

In this extract, the judge talks about the elements that infiltrated into Egypt through the tunnels and asks Mubarak about the reason they went to prisons and squares in large numbers. In answering the judge's questions, Mubarak displays full knowledge of the issue by using the two declarative sentences في السجون" (They went to prisons...Muslim Brotherhood) and "في الميادين...يضربوا نار" (In the squares...shot fire). These declarative sentences reflect Mubarak's certitude about the truth of the information he provides as well as his desire to assert that his responses are factual.

\section{Extract (19)}

القاضي: ما هي العلاقة بين اتفاقات جماعة الأخوان المسلمين حسبما أشرت مع عناصر

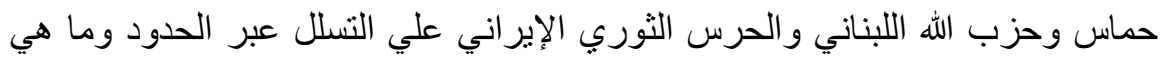

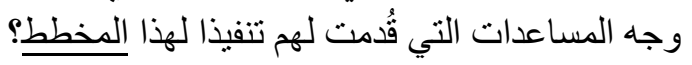

(Judge: What is the relation between the agreements held between the Muslim Brotherhood, as you stated, and elements from Hamas, Hezbollah and IRSC and the infiltration through the borders? How were they helped to implement this plan?)

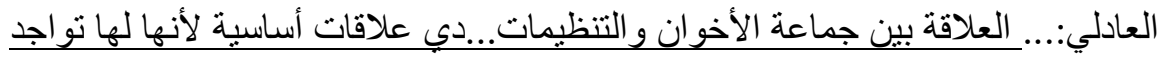

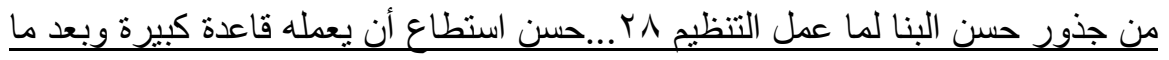

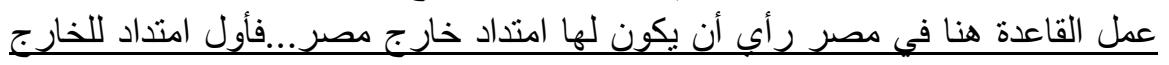

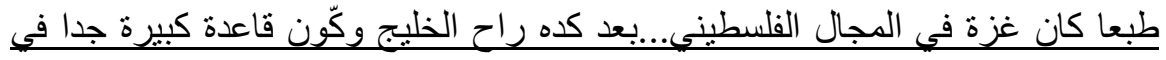
الخليج...استغل الأخوان التواجد ده في إن لما كان بيبقي في أب خلاف ما بي بين النظام في 
Epistemicity in Mubarak's and Al-Adly's Testimonies in the "Storming

Prisons and Eastern Borders" case: The Knowing, Unknowing and Believing Positions

Dr. Marwa Mohamed Khamis

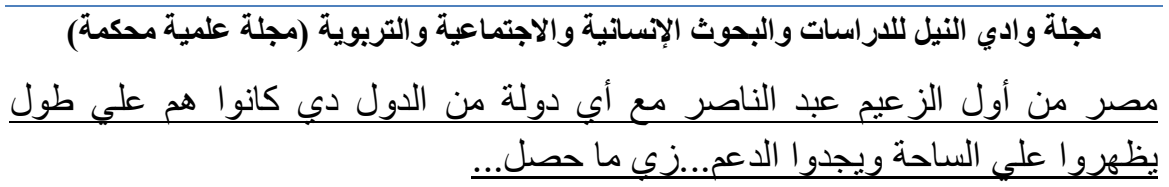

(Al-Adly: The relation between the Muslim Brotherhood and other organizations is essential as it has existed since Hassan El-Banna established the organization in 1928. He managed to establish a large base. After it was established in Egypt, it was decided to create extensions abroad, the first of which was in Gaza in Palestine. Then he went to the Gulf and established a huge base there. Members of the Muslim Brotherhood used this existence because whenever there was a disagreement between the regime in Egypt, starting from Abdel Nasser, and any country, they appeared and found support...like what happened.)

(Sada El-balad, 2018b)

In extract (19), Al-Adly is asked about the relation between the agreements held among the Muslim Brotherhood, Hamas, Hezbollah and IRSC and the illegal crossing of the borders as well as the help received to carry out the plan. To answer these questions, AL-Adly resorts to using a number of declarative sentences that have no evidential or epistemic markers. The aim of these declarative sentences is twofold. First, they serve to present historical facts about the emergence and spread of the Muslim Brotherhood as well as about how this organization took chance of any disagreement between the regime in Egypt and other countries to their benefit. Second, they communicate Al-Adly's complete knowledge of the background of the organizations he was asked about and how they work against the interests of different countries. 
مجلة وادي النيل للاراسات والبحوث الإنسانية والاجتماعية والتربوية (مجلة علمية محكمة)

(ISSN : 2536 - 9555)

\subsection{The Unknowing Position in Mubarak's and Al-Adly's Testimonies}

Mubarak and Al-Adly adopt the Unknowing position in their testimonies to display lack of knowledge in answering questions related to some details concerning the elements who stormed the Eastern borders, the deeds they perpetrated or the arrangement that took place between Hamas, Hezbollah, IRSC and the Muslim Brotherhood to illegally cross from Gaza and create chaos in Egypt. No morphosyntactic markers are employed to indicate Mubarak's and AL-Adly's lack of knowledge. Lexically, both witnesses express the Unknowing position through negating mental verbs of the Known. This is shown in extracts (20) and (21).

\section{$\underline{\text { Extract (20) }}$}

$$
\text { القاضي: هل شق هذه الأنفاق و العبور من خلالها كان بعلم الدولة؟ }
$$

(Judge: Did the State know about digging tunnels and crossing the borders through them?)

$$
\text { مبارك: الأنفاق دي قصة قديمة من قبل كده لكن استمرت لحد دلوقتي. }
$$

(Mubarak: The tunnels are an old story and had existed long before January 25.)

(Judge: Since when?)

$$
\text { القاضي: قبل كده من سنة كام؟ }
$$

مبارك: لا أتذكر السنين.

(Mubarak: I don't remember the years.)

(Sada El-balad, 2018a)

In this extract, when Mubarak is asked about whether the state knew about the presence of tunnels along the Eastern borders and their use to cross to Egypt, he replies saying that they had existed long before January 25 . When asked about the exact year in 
Epistemicity in Mubarak's and Al-Adly's Testimonies in the "Storming Prisons and Eastern Borders" case: The Knowing, Unknowing and Believing Positions

Dr. Marwa Mohamed Khamis

مجلة وادي النيل للاراسات والبحوث الإنسانية والاجتماعية والتريوية (مجلة علمية محكمة)

which these tunnels started to exist, Mubarak says "لا أتذكر السنين (I don't remember the years). In this reply, Mubarak negates the mental verb "أنذكر" (remember) to express lack of knowledge of this piece of information.

\section{Extract (21)}

القاضي: هل قامت قيادات الأخوان بمساعدة العناصر الأجنبية التي تسللت عبر الحدود الثرقية من عناصر حماس وحزب الله و الحرس الثورى الإبر اني في تنفيذ هذا المخطط؟ (Judge: Did leaders of the Muslim Brotherhood help foreign elements from Hamas, Hezbollah and IRSC who infiltrated through the Eastern borders to implement this plan?)

$$
\text { العادلي: معنديش تفاصيل للإجابة عن النقطة دي. }
$$

(Al-Adly: I don't know details to answer this question.)

(Sada El-balad, 2018b)

AL-Adly, in this extract, is asked about whether Muslim Brotherhood leaders helped elements from Hamas, Hezbollah and IRSC to cross the borders through the tunnels. By negating the mental verb saying "معنديش تفاصيل" (I don't know details), Al-Adly communicates his inability to provide an answer due to the absence of the required information.

\subsection{The Believing Position in Mubarak's and Al-Adly's}

\section{Testimonies}

In Mubarak's and Al-Adly's testimonies, the Believing position, which is the last epistemic stance, is indicated by markers that show the doubts, beliefs and assumptions of each witness. No morphosyntactic markers of the Believing stance have been found in the data. Of the lexical markers proposed by Zuczkowsi et al., (2014) to represent the Believing position, only epistemic verbal 
expressions and epistemic adjectives have been found. They are employed by Mubarak only, as shown in extracts (22) and (23).

\section{$\underline{\text { Extract (22) }}$}

$$
\text { القاضي: هل نجم عن ارتكاب هذه الأفعال أية وقائع قتل أو شروع في قتل؟؟ }
$$

(Judge: Did these acts result in any killings or attempted murder?)

(Mubarak: I'm not sure where...)

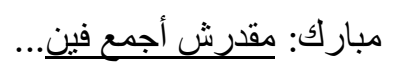

(Sada El-balad, 2018a)

In extract (22), the judge asks about the consequences of the deeds carried out by the elements who infiltrated into the Eastern borders and raided Egyptian prisons in 2011 to free members of the Muslim Brotherhood. He wants to know whether their actions led to killings or attempted murder. Mubarak's reply implies the presence of killings and/or attempted murder but his use of the epistemic verbal expression "مقدر أجمع فين" (I'm not sure where) indicates missing information concerning the whereabouts of these killings.

\section{$\underline{\text { Extract (23) }}$}

$$
\text { القاضي: طيب و إيه ر أيك في التنسيق اللي قاموا به؟ }
$$

(Judge: What do you think of the coordination between them?)

$$
\text { مبارك: كل حاجة جايزة...التنسيق والحاجات الصغيرة دي بنوصل للجهات الثانية. }
$$

(Mubarak: Everything is possible...Other authorities get to know about the coordination and such little things.)

(Sada El-balad, 2018a)

The judge, in this extract, asks Mubarak about his take on the coordination between Hamas and the Muslim Brotherhood to 
Epistemicity in Mubarak's and Al-Adly's Testimonies in the "Storming

Prisons and Eastern Borders" case: The Knowing, Unknowing and Believing Positions

Dr. Marwa Mohamed Khamis

مجلة وادي النيل للاراسات والبحوث الإنسانية والاجتماعية و التريوية (مجلة علمية محكمة)

create chaos in Egyptian streets. The gap in Mubarak's information in this regard is indicated by the use of the epistemic adjective "جايزة" (possible). By adopting a Believing position, Mubarak communicates uncertainty about the coordination between Hamas and members of the Muslim Brotherhood not only to infiltrate Egyptian borders but also to create chaos in the streets.

In Al-Adly's testimony, the Believing position is not indicated by any of Zuczkowski et al.'s (2014) lexical and morphosyntactic markers. Lexically, this epistemic stance is represented by adverbs such as "some", "about", "around" and "somewhere", as shown in extract (24).

\section{Extract (24)}

القاضي: هم دخلو ا ازاي؟

(Judge: How did they get in?)

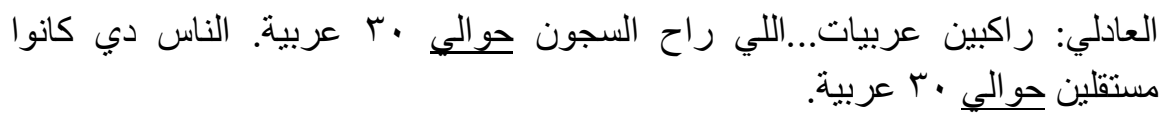

(Al-Adly: Using cars...Those who raided the prisons used around 30 cars. These people rode about 30 cars.)

(Sada El-balad, 2018b)

In this extract, Al-Adly is asked about the means the foreign elements used to storm the borders through the tunnels. Al-Adly tries to provide a precise answer not only by saying that these elements crossed the borders using cars but also by giving the number of cars used for this purpose. However, because he is not sure about the exact number of cars, he only gives an estimate number and indicates his uncertainty by using, and repeating, the adverb "حو الي" (around). 
The morphosyntactic markers employed in Al-Adly's testimony to represent the Believing position are phrases that reflect uncertain knowledge such as "as far as I know" and "as far as I can remember". An example of these phrases is given in extract (25).

\section{Extract (25)}

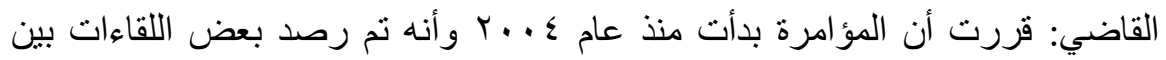

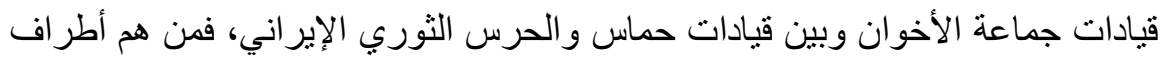

تلك اللقاءات وكيف كانت تترج

(Judge: You stated that the conspiracy started in 2004 and that a number of meetings between Muslim Brotherhood leaders and those of Hamas and IRSC were monitored. Who were in these meetings? How were they held?)

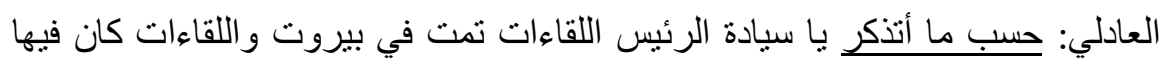

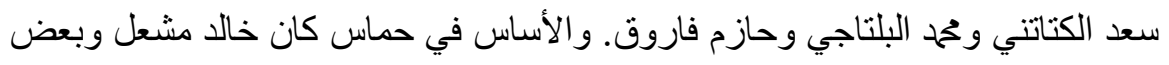

$$
\begin{aligned}
& \text { القيادات الأخري اللي مش في ذهني. }
\end{aligned}
$$

(Al-Adly: As far as I remember, your honor, the meetings were held in Beirut and were attended by Saad El-Katatni, Mohamed ElBaltagi and Hazem Farouk. The main parties in Hamas were Khaled Mashal and other leaders who slipped my mind.)

(Sada El-balad, 2018b)

In extract (25), Al-Adly is asked about the meetings held between leaders of the Muslim Brotherhood and those of Hamas and IRSC. He is required to mention where these meetings took place and the parties who attended them. Because AL-Adly is not sure about the whereabouts of the meetings or the names of Hamas leaders who attended them, he does not give a categorical answer. Rather, he expresses his uncertainty using the phrases حسب مكر" "مش في ذهني حاليا" (As far as I remember) and أنذكر" (slipped my mind) which reflect doubtful information or knowledge. 
Epistemicity in Mubarak's and Al-Adly's Testimonies in the "Storming Prisons and Eastern Borders" case: The Knowing, Unknowing and Believing Positions

Dr. Marwa Mohamed Khamis

مجلة وادي النيل للاراسات والبحوث الإنسانية والاجتماعية والتريوية (مجلة علمية محكمة)

\section{Results and Discussion}

The total number of questions addressed to Mubarak and Al-Adly is 144, 94 (65\%) of which are productive questions and 50 $(35 \%)$ are unproductive. This is in line with the nature of the trial in question which derives judges to ask more productive than unproductive questions to obtain vital information and details concerning the illegal crossing of Egypt's Eastern borders. The frequency of occurrence of the different types of productive and unproductive questions found in the data is presented in table (2).

Table (2): Frequency of occurrence of the types of productive and unproductive questions

\begin{tabular}{|c|c|c|c|}
\hline $\begin{array}{c}\text { Categories and } \\
\text { types }\end{array}$ & $\begin{array}{c}\text { Number of } \\
\text { questions } \\
\text { addressed to } \\
\text { Mubarak }\end{array}$ & $\begin{array}{l}\text { Number of } \\
\text { questions } \\
\text { addressed to } \\
\text { Al-Adly }\end{array}$ & Total \\
\hline $\begin{array}{l}\frac{\text { Productive }}{\underline{\text { questions }}} \\
\text { Open questions } \\
\text { Probing questions } \\
\text { Appropriate closed } \\
\text { yes/no questions }\end{array}$ & $\begin{array}{l}--- \\
30 \\
28\end{array}$ & $\begin{array}{c}6 \\
14 \\
16\end{array}$ & $\begin{array}{c}6(6 \%) \\
44(47 \%) \\
44(47 \%)\end{array}$ \\
\hline Total & $58(62 \%)$ & $36(38 \%)$ & $94(100 \%)$ \\
\hline $\begin{array}{l}\quad \frac{\text { Unproductive }}{\text { questions }} \\
\text { Inappropriate closed } \\
\text { yes/no questions } \\
\text { Leading questions } \\
\text { Multiple questions } \\
\text { Forced choice } \\
\text { questions }\end{array}$ & $\begin{array}{c}14 \\
6 \\
10 \\
---\end{array}$ & $\begin{array}{c}6 \\
-- \\
8 \\
6\end{array}$ & $\begin{array}{c}20(40 \%) \\
6(12 \%) \\
18(36 \%) \\
6(12 \%)\end{array}$ \\
\hline Total & $30(60 \%)$ & $20(40 \%)$ & $50(100 \%)$ \\
\hline
\end{tabular}




\section{مجلة وادي النيل للار اسات والبحوث الإنسانية والاجتماعية والتربوية (مجلة علمية محكمة)}

(ISSN : 2536 - 9555)

As shown in table (2), the number of productive questions addressed to Mubarak is more than those addressed to Al-Adly. While Mubarak receives 58 productive questions $(62 \%$ of the total number of productive questions), Al-Adly faces 36 productive questions $(38 \%$ of the total). Mubarak has also received unproductive questions more than Al-Adly (30 occurrences, 60\% of the total vs. 20 occurrences, $40 \%$ of the total). The difference in the frequency of occurrence can be attributed to the fact that Mubarak, due to his poor health condition at that time and the need for a permission to release classified information, gave rather short and direct answers. By contrast, Al-Adly tended to give elaborate, longish, detailed and sometimes evasive answers. Accordingly, it is possible that the different contributions and answering techniques of both witnesses drove the judge to ask productive and unproductive questions to Mubarak more than Al-Adly, hence the difference in the number of productive and unproductive questions asked to Mubarak and Al-Adly.

Table (2) shows that in terms of productive questions, open questions are directed to Al-Adly only but not to Mubarak probably because due to his position as Minister of the Interior during the 2011 events, he is capable of providing truthful and more accurate answers. Mubarak is asked more probing questions because he is required to clarify some details concerning the case in question. He is also asked more appropriate closed yes/no questions than Al-Adly as these questions help elicit short and specific answers which do not require further explanation and at the same time help the witness make conclusive remarks depending on the context of the question.

In terms of unproductive questions, table (2) shows that Mubarak is asked inappropriate closed yes/no questions and multiple questions more than Al-Adly. This can be attributed to the judge's desire to elicit the required answers. However, these poor 
Epistemicity in Mubarak's and Al-Adly's Testimonies in the "Storming Prisons and Eastern Borders" case: The Knowing, Unknowing and Believing Positions

Dr. Marwa Mohamed Khamis

مجلة وادي النيل للاراسات والبحوث الإنسانية والاجتماعية والتريوية (مجلة علمية محكمة)

questions allow witnesses to give evasive and unspecific answers rather than full and detailed ones. Leading and forced choice questions occur the same number of times (6 times). Leading questions are addressed to Mubarak only which suggests that the judge probably was trying to help Mubarak provide the required details by employing suggestive questions to suggest specific answers. Because sometimes Al-Adly's responses did not directly answer the judge's questions, forced choice questions were employed to corner him to provide the specific and required answers.

The data shows that Mubarak and Al-Adly make wide use of the three epistemic stances in question, namely the Knowing position, the Unknowing position and the Believing position. The total number of occurrences of the three positions is 630 . The most frequently occurring epistemic stance is the Knowing position as it occurs 567 times (90\% of the total) followed by the Unknowing position which occurs 36 times (6\% of the total) then the Believing position which occurs 27 (4\% of the total). The difference in the frequency of occurrence of the three epistemic stances shows Mubarak's and Al-Adly's greater tendency to communicate deep knowledge and absolute certainty, more than absence of knowledge or uncertainty, when providing particular information concerning storming Egypt's borders and prisons in 2011.

Lexical and morphosyntactic markers of the Knowing position, the Unknowing position and the Believing position differ in their frequency of occurrence in Mubarak's and Al-Adly's testimonies. Table (3) demonstrates the frequency of occurrence of lexical and morphosyntactic markers of the Knowing position in Mubarak's and Al-Adly's testimonies. 
مجلة وادي النيل للاراسات والبحوث الإنسانية والاجتماعية والتريوية (مجلة علمية محكمة)

(ISSN : 2536 - 9555)

Table (3): Frequency of occurrence of the markers of the Knowing position in the data

\begin{tabular}{|c|c|c|c|}
\hline Markers & $\begin{array}{c}\text { Frequency in } \\
\text { Mubarak's } \\
\text { testimony }\end{array}$ & $\begin{array}{c}\text { Frequency in } \\
\text { Al-Adly's } \\
\text { testimony }\end{array}$ & Total \\
\hline \multicolumn{4}{|l|}{ Lexical Markers } \\
\hline Evidential verbs & 5 & 10 & $15(24 \%)$ \\
\hline $\begin{array}{l}\text { Epistemic verbal } \\
\text { expressions }\end{array}$ & --- & --- & --- \\
\hline Epistemic adverbials & 14 & 20 & $34(54 \%)$ \\
\hline $\begin{array}{l}\text { Shared epistemic } \\
\text { knowledge }\end{array}$ & 4 & 10 & $14(22 \%)$ \\
\hline Total & $23(36.5 \%)$ & $40(63.5 \%)$ & $63(100 \%)$ \\
\hline$\frac{\text { Morphosyntactic }}{\text { Markers }}$ & & & \\
\hline $\begin{array}{l}\text { Past, present and } \\
\text { future declarative } \\
\text { sentences with no } \\
\text { lexical evidential or } \\
\text { epistemic markers }\end{array}$ & $204(40 \%)$ & $300(60 \%)$ & $504(100 \%)$ \\
\hline Total & 227 & 340 & 567 \\
\hline
\end{tabular}

Table (3) shows that the lexical and morphosyntactic markers representing the Knowing position in Al-Adly's testimony outnumber those employed in Mubarak's testimony. The lexical markers occur 40 times $(63.5 \%$ of the total number of the lexical markers of the Knowing position) in the former's testimony. They occur 23 times $(36.5 \%$ of the total) in the latter's. While there are 300 occurrences of morphosyntactic markers $(60 \%$ of the total number of these markers) in Al-Adly's testimony, there are 204 occurrences (40\% of the total) in Mubarak's testimony. This shows that in adopting this epistemic position, Al-Adly, based on what he perceives (evidentiality) or deducts (epistemicity), seeks to convey 
Epistemicity in Mubarak's and Al-Adly's Testimonies in the "Storming Prisons and Eastern Borders" case: The Knowing, Unknowing and Believing Positions

Dr. Marwa Mohamed Khamis

مجلة وادي النيل للاراسات والبحوث الإنسانية والاجتماعية والتريوية (مجلة علمية محكمة)

information as known, certain and thus true more than Mubarak. Al-Adly's use of lexical and morphosyntactic markers more frequently than Mubarak is attributed to the nature of the testimony given by each speaker. Mubarak's answers to the judge's questions are rather short, direct and to the point. Sometimes he also repeats the answers given to different questions. On the other hand, AlAdly provides lengthy, elaborate and sometimes irrelevant answers to some questions. His detailed replies, in which he expresses knowledge of the jail break issue, can be explained in light of the fact that because of his position during the 2011 events, he had all the necessary and incontestable information concerning the illegal crossing of Egypt's Eastern borders and prison breaks. This explains Al-Adly's desire to assert the truth and certainty of the information provided in his testimony.

Concerning the Unknowing position, no morphosyntactic markers have been found in the data. Table (4) presents the frequency of occurrence of the lexical markers of the Unknowing position in Mubarak's and Al-Adly's testimonies.

Table (4): Frequency of occurrence of the lexical markers of the Unknowing position

\begin{tabular}{|l|c|c|c|}
\hline Lexical Markers & $\begin{array}{c}\text { Frequency of } \\
\text { occurrence in } \\
\text { Mubarak's } \\
\text { testimony }\end{array}$ & $\begin{array}{c}\text { Frequency of } \\
\text { occurrence in } \\
\text { Al-Adly's } \\
\text { testimony }\end{array}$ & Total \\
\hline $\begin{array}{l}\text { Negative form of } \\
\text { the evidential verbs } \\
\text { of the Known }\end{array}$ & $30(83 \%)$ & $6(17 \%)$ & $36(100 \%)$ \\
\hline
\end{tabular}

119 
As shown in table (4), the Unknowing position in Mubarak's and Al-Adly's testimonies is represented using the negative form of the evidential verbs of the Known only. While this lexical marker occurs 30 times $(83 \%$ of the total number of occurrences of this marker in the data) in Mubarak's testimony, it occurs 6 times only $(17 \%)$ in Al-Adly's testimony. The discrepancy in the frequency of occurrence of this lexical marker in the testimony of Mubarak and Al-Adly reflects the huge gap in the information Mubarak has concerning the infiltration of foreign elements into the country and storming prisons to free Muslim Brotherhood leaders. Mubarak's lack of knowledge or missing information can partly be attributed to his age and health condition and partly to his desire not to disclose classified information before getting President Abdel Fattah El-Sisi's permission to do so. As a Minister of the Interior in 2011, Al-Adly was always kept up to date with the goings on at that time. Therefore, because he was well-informed about the events, there was no room for his not knowing important information except for details which, as he maintains, are known to other authorities in the country. This explains the low number of occurrences of lexical markers denoting the Unknowing position in Al-Adly's testimony.

Table (5) demonstrates the frequency of occurrence of the lexical and morphosyntactic markers denoting the Believing position in Mubarak's and Al-Adly's testimonies. 
Epistemicity in Mubarak's and Al-Adly's Testimonies in the "Storming Prisons and Eastern Borders" case: The Knowing, Unknowing and Believing Positions

Dr. Marwa Mohamed Khamis

مجلة وادي النيل للاراسات والبحوث الإسانية والاجتماعية والتربوية (مجلة علمية محكمة)

Table (5): Frequency of occurrence of the lexical and morphosyntactic markers of the Believing position in the data

\begin{tabular}{|l|c|c|c|}
\hline Lexical Markers & $\begin{array}{c}\text { Frequency of } \\
\text { occurrence in } \\
\text { Mubarak's } \\
\text { testimony }\end{array}$ & $\begin{array}{c}\text { Frequency of } \\
\text { occurrence in } \\
\text { Al-Adly's } \\
\text { testimony }\end{array}$ & Total \\
\hline $\begin{array}{l}\text { Lexical Markers } \\
\text { Verbal epistemic } \\
\text { expressions } \\
\text { Epistemic adjectives } \\
\text { Adverbs }\end{array}$ & 9 & --- & $9(39 \%)$ \\
\hline Total & 10 & --- & $10(44 \%)$ \\
\hline $\begin{array}{l}\text { Morphosyntactic } \\
\text { Markers }\end{array}$ & --- & 4 & $4(17 \%)$ \\
\hline $\begin{array}{l}\text { Pharses with } \\
\text { markers of } \\
\text { uncertain } \\
\text { knowledge }\end{array}$ & --- & $4(17 \%)$ & $23(100 \%)$ \\
\hline \multicolumn{1}{c|}{ Total } & & 4 & 4 \\
\hline
\end{tabular}

In table (5), the lexical markers denoting the Believing position in Mubarak's testimony outnumber those in Al-Adly's testimony. Whereas there are 19 occurrences of these markers $(83 \%$ of the total) in Mubarak's testimony, there are 4 occurrences only (17\%) in Al-Adly's testimony. This reflects a higher degree of uncertainty about some of the information he provides. Mubarak's uncertainty can be attributed to his age and health conditions which might have made him unable to remember some information. It can also be attributed to the fact that, as he says in his testimony, as a President he was only given general information about the case in question but not the details which were only known to certain authorities. 
The Ministry of the Interior is one of these authorities, hence the small number of lexical as well as morphosyntactic markers in AlAdly's testimony.

The study has investigated the relation between the types of the questions asked to Mubarak and Al-Adly and the Knowing, Unknowing and Believing positions they take in their testimonies. It has been found that the stances in question occur in different frequencies when they are adopted in answering the different types of questions addressed to both witnesses. The frequency of occurrence of the three stances adopted when answering the productive and unproductive questions found in the data is shown in table (6).

Table (6): Frequency of occurrence of the Knowing, Unknowing and Believing positions in relation to the different types of productive and unproductive questions

\begin{tabular}{|l|c|c|c|c|c|c|}
\hline $\begin{array}{c}\text { Types of } \\
\text { questions }\end{array}$ & \multicolumn{3}{|c|}{ Mubarak's testimony } & \multicolumn{3}{c|}{ Al-Adly's testimony } \\
\hline $\begin{array}{l}\text { Productive } \\
\text { questions }\end{array}$ & Knowing & Unknowing & Believing & Knowing & Unknowing & Believing \\
\hline $\begin{array}{l}\text { Open } \\
\text { questions }\end{array}$ & --- & --- & --- & 41 & --- & --- \\
\hline $\begin{array}{l}\text { Probing } \\
\text { questions }\end{array}$ & 70 & 9 & 9 & 70 & 2 & 2 \\
\hline $\begin{array}{l}\text { Appropriate } \\
\text { closed yes/no } \\
\text { questions }\end{array}$ & 85 & 6 & --- & 130 & 2 & 2 \\
\hline \multicolumn{1}{|c|}{ Total } & 155 & $15(50 \%)$ & $\begin{array}{c}9 \\
(47 \%)\end{array}$ & $\begin{array}{c}241 \\
(71 \%)\end{array}$ & $4(67 \%)$ & 4 \\
& $(68 \%)$ & & $\begin{array}{c} \\
(50 \%)\end{array}$ \\
\hline
\end{tabular}


Epistemicity in Mubarak's and Al-Adly's Testimonies in the "Storming Prisons and Eastern Borders" case: The Knowing, Unknowing and Believing Positions

Dr. Marwa Mohamed Khamis

مجلة وادي النيل للاراسات والبحوث الإنسانية والاجتماعية والتريوية (مجلة علمية محكمة)

\begin{tabular}{|c|c|c|c|c|c|c|}
\hline $\begin{array}{l}\text { Unproductive } \\
\text { questions } \\
\text { Inappropriate } \\
\text { closed yes/no } \\
\text { questions }\end{array}$ & 40 & 7 & 10 & 40 & --- & 2 \\
\hline $\begin{array}{l}\text { Leading } \\
\text { questions }\end{array}$ & 32 & 4 & --- & --- & --- & --- \\
\hline $\begin{array}{l}\text { Multiple } \\
\text { questions }\end{array}$ & --- & 4 & --- & 23 & 2 & 2 \\
\hline $\begin{array}{l}\text { Forced } \\
\text { choice } \\
\text { questions }\end{array}$ & --- & --- & --- & 36 & --- & --- \\
\hline Total & $\begin{array}{c}72 \\
(32 \%)\end{array}$ & $15(50 \%)$ & $\begin{array}{c}10 \\
(53 \%)\end{array}$ & $\begin{array}{c}99 \\
(29 \%)\end{array}$ & $2(33 \%)$ & $\begin{array}{c}4 \\
(50 \%)\end{array}$ \\
\hline & $\begin{array}{c}227 \\
(100 \%) \\
\end{array}$ & $\begin{array}{c}30 \\
(100 \%) \\
\end{array}$ & $\begin{array}{c}19 \\
(100 \%)\end{array}$ & $\begin{array}{c}340 \\
(100 \%)\end{array}$ & $6(100 \%)$ & $\begin{array}{c}8 \\
(100 \%)\end{array}$ \\
\hline
\end{tabular}

Table (6) shows that both Mubarak and Al-Adly adopt the Knowing position when answering productive questions more than unproductive ones. Mubarak adopts this position 155 times (68\% of the total number of occurrences of the Knowing position in Mubarak's testimony which is 227) when answering productive questions and 72 times (32\%) when answering unproductive ones. Al-Adly adopts the Knowing position 241 times (71\% of the total number of occurrences of this position in Al-Adly's testimony which is 340) when answering productive questions and 99 times (29\%) when answering unproductive ones. Concerning the Unknowing position, Mubarak adopts this position the same number of times when answering productive and unproductive questions (15 occurrences, 50\%). Al-Adly adopts the Unknowing position when answering productive questions more than 
unproductive ones (4 occurrences, $67 \%$ vs. 2 occurrences, 33\%). As for the Believing position, it is adopted by Mubarak when answering unproductive questions more than when answering productive ones (10 occurrences, $53 \%$ vs. 9 occurrences, $47 \%$ ). AlAdly adopts the Believing position the same number of times in answering productive and unproductive questions (4 times, 50\%). Thus, productive questions trigger responses that encourage the adoption of the Knowing position more frequently in Mubarak's and Al-Adly's testimonies. This reflects the desire of both witnesses to convey full knowledge about the sensitive case in question by providing all the information and details they know about this issue.

In terms of productive questions, table (6) shows that the only position adopted by Al-Adly when answering open questions is the Knowing position since these questions require him to provide an accurate account of the events inquired about in these questions. Both Mubarak and Al-Adly adopt the Knowing position the same number of times (70 times) when answering probing questions as these questions require specific answers and details so as to give a full account of the story. Whereas Al-Adly adopts the Unknowing and Believing positions twice only when answering probing questions, Mubarak adopts these positions 9 times. This can be attributed to Mubarak's inability to remember certain details or his ignorance about these details. Moreover, when answering appropriate closed yes/no questions, Al-Adly adopts the Knowing position more than Mubarak (130 times vs. 85 times). This is in line with Al-Adly's tendency to give longish and detailed answers in which he conveys his knowledge of important information concerning the infiltration through the borders. Despite the difference in the number of times in which Mubarak and Al-Adly adopt the Knowing position in answering appropriate closed yes/no questions, both witnesses share the fact that they adopt this 
Epistemicity in Mubarak's and Al-Adly's Testimonies in the "Storming Prisons and Eastern Borders" case: The Knowing, Unknowing and Believing Positions

Dr. Marwa Mohamed Khamis

مجلة وادي النيل للاراسات والبحوث الإسانية والاجتماعية والتريوية (مجلة علمية محكمة)

position more frequently when answering this type of productive questions more than the other types of the same category, i.e. productive questions. This is important as these questions enable witnesses to clarify key points and thus help establish conclusive and legal points about the case in question. The importance of appropriate closed yes/no questions also helps explain the few number of occurrences of the Unknowing and Believing positions in Mubarak's and Al-Adly's testimonies.

As for unproductive questions, table (6) shows that Mubarak and Al-Adly adopt the Knowing position 40 times when answering inappropriate closed yes/no questions. This indicates that both witnesses opt to provide knowledgeable answers even though these questions allow them to provide less-detailed ones. These unspecific answers are shown in Mubarak's adoption of the Unknowing and Believing positions less frequently than the Knowing position when answering this type of unproductive questions to convey uncertainty and lack of knowledge. He also adopts the Believing position more than Al-Adly (10 occurrences vs. 2 occurrences) when answering inappropriate closed yes/no questions for the same reason. Because leading questions are suggestive in nature, they encourage Mubarak to provide answers in which he adopts the Knowing position more frequently than the Unknowing position (32 occurrences vs. 4 occurrences). Since multiple questions include several sub-types and forced choice questions limit the number of responses available to a speaker, AlAdly adopts the Knowing position more than the Unknowing and Believing positions when answering multiple questions. He also adopts the Knowing position only when answering forced choice questions. Mubarak only adopts the unknowing position to answer multiple questions. Although inappropriate closed yes/no 


\section{مجلة وادي النيل للاراسات والبحوث الإسانية والاجتماعية والتربوية (مجلة علمية محكمة)}

(ISSN : 2536 - 9555)

questions, leading questions, multiple questions and forced choice questions are categorized as unproductive questions, the analysis has revealed that they encouraged Mubarak and Al-Adly to adopt the knowing position more than the Unknowing and believing positions, thereby displaying full knowledge of the details and events concerning trespassing Egypt's Eastern borders.

\section{Conclusion}

The present study has investigated epistemicity in the testimony of former President Mohamed Hosni Mubarak and his Minister of the Interior Habib Al-Adly. The Griffiths Question Map proposed by Griffiths and Milne (2006) and the Knowing, Unknowing and Believing model developed by Zuczkowski et al. (2014) have been employed to examine the questions asked to Mubarak and Al-Adly and the epistemic stances adopted by both witnesses, namely the Knowing position, the Unknowing position and the Believing position. In this regard, the study has attempted to answer three research questions. First, what are the types of questions asked by the judge in the court case of storming Egypt's Eastern borders and springing key Muslim Brotherhood figures from prison? Second, how is epistemicity constructed in the testimony of Mubarak and Al-Adly? Third, what is the relation between the types of questions asked and the Knowing, Unknowing and Believing positions adopted by Mubarak and AlAdly in their testimonies?

Concerning the first research question, the analysis has shown that productive and unproductive questions are addressed to both Mubarak and Al-Adly. Mubarak has received both types of questions more frequently than Al-Adly. In terms of the productive questions, open questions are asked to Al-Adly only and although

probing questions and appropriate closed yes/no questions are addressed to both witnesses, they are put to Mubarak more than Al- 
Epistemicity in Mubarak's and Al-Adly's Testimonies in the "Storming Prisons and Eastern Borders" case: The Knowing, Unknowing and Believing Positions

Dr. Marwa Mohamed Khamis

مجلة وادي النيل للاراسات والبحوث الإنسانية والاجتماعية والتريوية (مجلة علمية محكمة)

Adly. As for unproductive questions, it has been found that inappropriate closed yes/no questions and multiple questions are addressed to Mubarak more frequently than Al-Adly. Leading questions and forced choice questions occur the same number of times in the data. Whereas leading questions are addressed to Mubarak only, forced choice questions are put to Al-Adly only.

Regarding the second research question, the analysis reveals that Mubarak and Al-Adly construct epistemicity in their testimonies by adopting three epistemic positions: the Knowing position, the Unknowing position and the Believing position. These positions are represented by using a number of lexical and morphosyntactic markers. The number of lexical and morphosyntactic markers of the Knowing position in Al-Adly's testimony is higher than their number in Mubarak's testimony. Of the lexical markers of the Knowing position developed by Zuczkowski et al. (2014) only evidential verbs and epistemic adverbials have been found in the data. It has also been found that one more lexical marker which is not included in Zuczkowski et al.'s framework is used to represent the Knowing position, namely expressions that refer to shared epistemic knowledge. Zuczkowski et al.'s morphosyntactic markers of the Knowing position are employed in the data. These are clauses in the present, past and future with no lexical evidential or epistemic markers.

No morphosyntactic markers of the Unknowing position have been found in the data. Lexically, the Unknowing position is represented in Mubarak's and Al-Adly's testimonies by using the negative form of the evidential verbs of the known. No instances of adjectives with negative prefixes or negative copular verbs used to lexically represent the Unknowing position have been found. 
Of the lexical markers of the Believing position put forward by Zuczkowski et al., only verbal epistemic expressions, epistemic adjectives and adverbs have been found in the data. While the first two markers have been found in Mubarak's testimony only, adverbs have been employed only by Al-Adly. The frequency of occurrence of the lexical markers of the Believing position in Mubarak's testimony is higher than in Al-Adly's. None of the morphosyntactic markers of the Believing position given in Zuczkowski et al.'s framework have been employed in Mubarak's and Al-Adly's testimonies. Rather, it has been found that the only morphosyntactic markers of this epistemic position in the data are phrases that include markers of uncertain knowledge. These markers have been found in Al-Adly's testimony only but not in Mubarak's.

With respect to the third research question, the analysis reveals that when answering productive and unproductive questions, both Mubarak and Al-Adly adopt the Knowing position more than the Unknowing and Believing positions. The Knowing position occurs more frequently when answering productive, rather than unproductive, questions in the testimonies of both witnesses. The Unknowing position is adopted by Mubarak an equal number of times when answering productive and unproductive questions. It is adopted by Al-Adly when answering productive questions more than unproductive ones. Whereas the Believing position is adopted by Mubarak more when answering unproductive, rather than productive, questions, it is adopted by Al-Adly equally when answering both productive and unproductive questions.

As for the types of productive questions, it has been found that when answering open questions, which are not addressed to Mubarak, Al-Adly adopts the Knowing position only. When answering probing questions, both witnesses adopt the Knowing position more than the Unknowing and Believing positions. 
Epistemicity in Mubarak's and Al-Adly's Testimonies in the "Storming Prisons and Eastern Borders" case: The Knowing, Unknowing and Believing Positions

Dr. Marwa Mohamed Khamis

مجلة وادي النيل للاراسات والبحوث الإسانية والاجتماعية والتربوية (مجلة علمية محكمة)

Mubarak adopts the Unknowing and Believing positions the same number of times when answering probing questions and so does Al-Adly. The frequency of occurrence of these two positions when answering this type of questions is higher in Mubarak's testimony. When answering appropriate closed yes/no questions, both Mubarak and Al-Adly adopt the Knowing position more than the Unknowing and Believing positions. However, the frequency of occurrence of this position when answering this type of questions is higher in Al-Adly's testimony. Moreover, when answering appropriate closed yes/no questions, Mubarak adopts the Unknowing position more than the Believing position whereas these two positions are adopted the same number of times in AlAdly's testimony when answering this type of questions.

With regards to the types of unproductive questions, the data shows that the Knowing position is adopted by Mubarak and Al-Adly an equal number of times when answering inappropriate closed yes/no questions. It is also adopted by both witnesses more frequently than the Unknowing and Believing positions. Mubarak's adoption of the Believing position is higher than Al-Adly's. When answering this type of unproductive questions, Al-Adly does not adopt the Unknowing position. It is adopted only by Mubarak. Leading questions, which are not addressed to Al-Adly, are answered by Mubarak by adopting the Knowing position more than the Unknowing one. He does not take the Believing position to answer leading questions. Mubarak adopts the Unknowing position only to answer multiple questions. Al-Adly answers multiple questions by adopting the Knowing position more than the Unknowing and Believing positions which he adopts equally to answer these questions. Forced choice questions, which are not 
addressed to Mubarak, are answered by Al-Adly by adopting the Knowing position only.

The findings of the present study underscore the role language plays in courtrooms to exercise power and control through the question-answer exchanges that take place in court trials. The different types of questions asked in the courtroom help elicit substantial information. This is because the analysis has shown that not only productive questions but also unproductive ones have been employed to give a full account of the events and circumstances surrounding the court case of storming Egypt's Eastern borders and raiding prisons to free Muslim Brotherhood figures. Indeed, it has been found that the unproductive questions employed in the data, namely inappropriate closed yes/no questions, leading questions, multiple questions, and forced choice questions are answered by adopting the Knowing position more frequently than the Unknowing and Believing positions by Mubarak and Al-Adly so as to express their certainty of the information they provide and thus assert the truth of their statements.

The findings of the study also shed light on the ways in which Mubarak's and Al-Adly's testimonies are epistemically constructed to communicate known, unknown or believed information concerning the court case in question. Through employing a number of lexical and morphosyntactic markers to convey the three epistemic positions, Mubarak and Al-Adly, as key witnesses, presented important evidence that helped determine the outcome and the verdict of the case as the Cairo Criminal Court passed a life sentence on a number of key Muslim Brotherhood leaders and figures.

As epistemicity is at the heart of legal discourse as it can be constructed by formulating different types of questions, future research can examine it in other cases that received wide attention 


\section{Epistemicity in Mubarak's and Al-Adly's Testimonies in the "Storming Prisons and Eastern Borders" case: The Knowing, Unknowing and Believing Positions}

Dr. Marwa Mohamed Khamis

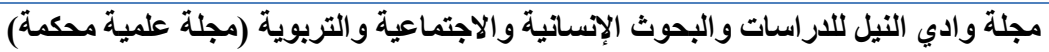

such as the case known as the "trial of the century", the "Rabaa dispersal" case and the "Qatar espionage" case. Epistemicity can also be investigated in parliamentary discourse to study the different types of questions asked by members of the Parliament to ministers and how the latter take up the Knowing, Unknowing and Believing epistemic positions to convey having certain, uncertain or no knowledge or information concerning key matters they are responsible for. Future research can also examine epistemicity in media discourse by studying, for example, how politicians and non-politicians construct different epistemic stances on different domestic and foreign issues. These studies can also be carried out cross-culturally.

\section{Transcription Convention}

... omitted speech

\section{References}

Al-Gublan, B.K. (2015). A linguistic study of language power and strategy used by jurists. International Journal of Language and Linguistics, 2(3), 165-182.

Biber, D., Johansson, S., Leech, G., Conrad, S., \& Finegan, E. (1999). The Longman grammar of spoken and written English. London: Longman.

Biscetti, S. (2006). Tag questions in courtroom discourse. In M. Gotti \& J. Flowerdew (Eds.), Studies in specialized discourse (pp. 209238). Bern: Peter Lang.

Bongelli, R., Canestrari, C., Riccioni, I., Zuczkowski, A., Buldorini, C., Pietrobon, R., Lavelli, A., \& Magnini, B. (2012). A corpus of scientific biomedical texts by spanning over 168 years annotated for uncertainty. In N. Calzolari, K. Choukri, T. Declerck, M. 
Dogan, B. Maegaard, J. Mariani, J. Odijk, \& S. Piperidis (Eds.), Proceedings of the Eighth International Conference on Language Resources and Evaluation (LREC), vol. 12 (pp. 2009-2014). Istanbul: European Language Resources Association (ELRA).

Bongelli, R., Riccioni, I., Burro, R., \& Zuczkowski, A. (2013). Certainuncertain, true-false, good-evil in Italian political speeches. In I. Poggi, F. D'Errico, L. Vincze, \& A. Vinciarelli (Eds.), Multimodal communication in political speech: Shaping minds and social action (pp. 164-180). London: Springer. https://doi.org/10.1007/978-3-642-41545-6_13

Bongelli, R., Riccioni, I., Burro, R., \& Zuczkowski, A. (2019). Writer's uncertainty in scientific and popular biomedical articles: A comparative analysis of the British Medical Journal and Discover Magazine. $\quad P L o S \quad O N E, \quad 14(9), \quad$ 1-26. https://doi.org/10.1371/journal.pone.0221933

Catoto, J.S. (2017). On courtroom questioning: A forensic linguistic analysis. IOSR Journal of Humanities and Social Science, 22(11), 65-97.

Ceballos, C.T., \& Sosas, R.V. (2018). On court proceedings: A forensic linguistic analysis on maxim violation. Journal of Nusantara Studies, $3(2)$, 17-31. http://dx.doi.org/10.24200/jonus.vol3iss2pp17-31

Chang, Y. (2004). Courtroom questioning as a culturally situated persuasive genre of talk. Discourse and Society, 15(6), 705-722.

Cheng, L., \& Jiamin, P. (2018, May). A pragmatic turn in the interpretation of court judgments. In L. Hale \& J. Zhang (Eds.), The Proceedings of the Fifth International Conference on Law and Language of the International Academy of Linguistic Law (IALL2017): Law, Language and Justice (pp. 23-30). Marietta, Georgia: The American Scholars Press.

Cheng, W., \& Cheng, L. (2014). Epistemic modality in court judgments: A corpus-driven comparison of civil cases in Hong Kong and Scotland. English for Specific Purposes,33(1), 15-26. 


\section{Epistemicity in Mubarak's and Al-Adly's Testimonies in the "Storming Prisons and Eastern Borders" case: The Knowing, Unknowing and Believing Positions}

Dr. Marwa Mohamed Khamis

مجلة وادي النيل للاراسات والبحوث الإنسانية والاجتماعية والتريوية (مجلة علمية محكمة)

Coulthard, M., \& Johnson, A. (2010). Concluding remarks: Future directions in forensic linguistics. In M. Coulthard \& A. Johnson (Eds.), The Routledge handbook of forensic linguistics (pp. 602614). London: Routledge.

Cruz, S., \& Parina, J.C. (2015, March). Legal English in court resolutions: A stylistic analysis. Paper presented at the DLSU Research Congress. De La Salle University, Manila, Philippines.

Dong, J. (2013). Interpersonal metaphor in legal discourse: Modality in cross-examinations. Journal of Language Teaching and Research, 4(6), 1311-1321.

Du Bois, J. (2007). The stance triangle. In R. Englebretson (Ed.), Stancetaking in discourse (pp. 139-182). Amsterdam/Philadelphia: John Benjamins.

Eades, D. (2008). Telling and Retelling your story in court: Questions, assumptions and intercultural implications. Current Issues in Criminal Justice, 20(2), 209-230.

Farinde, R.O. (2008). Forensic linguistics: An introduction to the study of language and the law. Ago-Iwoye: Olabisi Onabanjo University Press.

Gibbons, J. (2008). Questioning in common law criminal courts. In J. Gibbons \& M.T. Turell (Eds.), Dimensions of forensic linguistics (pp. 115-130). Amsterdam/Philadelphia: John Benjamins.

Griffiths, A., \& Milne, B. (2006). Will it all end in tiers? Police interviews with suspects in Britain. In T. Williamson (Ed.), Investigative interviewing: Rights, research and regulation (pp. 167-189). Cullompton: Willan Publishing.

Hernandez, H.P. (2017). A (forensic) stylistic analysis of adverbials of attitude and emphasis in Supreme Court decisions in Philippine English. Indonesian Journal of Applied Linguistic, 7(2), 455-466.

Hobbs, P. (2003). "'You must say it for him': Reformulating a witness' testimony on cross-examination at trial". Text, 23(4), 477-511. 
Holt, E., \& Johnson, A. (2010). Legal talk: Socio-pragmatic aspects of legal talk: Police interviews and trial discourse. In M. Coulthard \& A. Johnson (Eds.), The Routledge handbook of forensic linguistics (pp. 21-36). Abingdon: Routledge.

Ibanez, C.V., \& Kotwica, D. (2020).'Tell us only what you know': Evidentiality in the discourse of participants in Spanish trials. Corpus Pragmatics, 4(1), 133-153. https://doi.org/10.1007/s41701-019-00070-z

Jianmin, C. (2015, September). Metaphor in lawyer's argumentative courtroom discourse. In C. Le, L. Ervo, J. Li, L. Hale, \& J. Zhang (Eds.). The Proceedings of the Fifth International Conference on Law, Language and Discourse (pp. 51-56). Marietta, Georgia: The American Scholars Press.

Keisanen, T. (2007). Stancetaking as an interactional activity: Challenging the prior speaker. In R. Englebretson (Ed.), Stancetaking in discourse (pp. 253-281). Amsterdam/Philadelphia: John Benjamins.

Le, C., Kui, S., \& Ying-Long, Z. (2008). Contrastive analysis of Chinese and American court judgments. Critical Approaches to Discourse Analysis across Disciplines, 2(1), 49-58.

Marin-Arrese, J.I. (2011). Effective vs. epistemic stance and subjectivity in political discourse: Legitimising strategies and mystification of responsibility. In C. Hart (Ed.), Critical discourse studies in context and cognition (pp. 193-223). Amsterdam/Philadelphia: John Benjamins.

Marin-Arrese, J.I. (2013). Stancetaking and inter/subjectivity in the Iraq inquiry: Blair vs. Brown. In J.I. Marin-Aresse, M. Carretero, J. ArusHita, \& J. vander Auwera (Eds.), English modality: Core, periphery and evidentiality (pp. 411-445). Berlin: De Gruyter Mouton.

Marin-Arrese, J.I. (2015). Epistemicity and stance: A cross linguistic study of epistemic stance strategies in journalistic discourse in English and Spanish. Discourse Studies, 17(2), 210-225. 


\section{Epistemicity in Mubarak's and Al-Adly's Testimonies in the "Storming Prisons and Eastern Borders" case: The Knowing, Unknowing and Believing Positions}

Dr. Marwa Mohamed Khamis

مجلة وادي النيل للاراسات والبحوث الإنسانية والاجتماعية والتريوية (مجلة علمية محكمة)

Mazzi, D. (2010). "This argument fails for two reasons...": A linguistic analysis of judicial evaluation strategies in US Supreme Court judgments. International Journal for the Semiotics of Law, 23(4), 373-385.

Minni, G., Scardigno, R., \& Grattagliano, I. (2014). The dialogic construction of certainty in legal contexts. Language and Dialogue, 4(1), 112-131.

Moneva, M.A. (2013). Cognition and context of legal texts: Spanish and English judgments compared. Revista de Linguistica y Lenguas Aplicadas, 8, 76-92. http://dx.doi.org/10.4995/rlyla.2013.1245

Monsefi, R. (2012). Language in criminal justice: Forensic linguistics in Shipman trial. International Journal of Law, Language \& Discourse, 2(2), 43-69.

Mooney, A. (2014). Language and Law. New York: Palgrave Macmillan.

Mortensen, S., \& Mortensen, J. (2017). Epistemic stance in courtroom interaction. In F. Poggi \& A. Capone (Eds.), Pragmatics and Law: Practical and theoretical perspectives (pp. 401-437). Cham: Springer.

Olanrewaju, F. (2010). Forensic linguistics: Power and asymmetries in the Nigerian courtroom discourse. Unizik Journal of Arts and Humanities, 2(2), 236-269.

Olsson, J. (2004). Forensic linguistics: An introduction to language, crime, and the law. London: Continuum.

Olsson, J. (2008). Forensic linguistics $\left(2^{\text {nd }}\right.$ ed.). London and New York: Continuum.

Oxburgh, G., Myklebust, T., Grant, T., \& Milne, R. (2016). Communication in investigative and legal settings: Introduction and contexts. In G. Oxburgh, T. Myklebust, T. Grant, \& R. Milne (Eds.), Communication in investigative and legal contexts: Integrated approaches from forensic psychology, linguistics and law enforcement (pp. 1-13). London: Wiley Blackwell. 
(ISSN : 2536 - 9555)

Pei, J. (2015, September). Study on Chinese civil court judgments: A Gricean perspective. In C. Le, L. Ervo, J. Li, L. Hale, \& J. Zhang (Eds.), The Proceedings of the Fifth International Conference on Law, Language and Discourse (pp. 170-177). Marietta, Georgia: The American Scholars Press.

Philip, G., Bongelli, R., Canestrari, C., Riccioni, I., \& Zuczkowski, A. (2013). Negotiating narrative: Dialogic dynamics of known, unknown and believed in Harry Potter and The Deathly Hallows. Language and Dialogue, 3(1), 6-32.

Ranosa-Madrunio, M. (2013). The interrogator and the interrogated: The questioning process in Philippine courtroom discourse. Philippine Journal of Linguistics, 43, 43-60.

Riccioni, I., Bongelli, R., \& Zuczkowski, A. (2013). The communication of certainty and uncertainty in Italian political media discourses. In A. Fetzer (Ed.), The pragmatics of political discourse: Explorations across cultures (pp. 125-165). Amsterdam/Philadelphia: John Benjamins.

Sanni, O. (2016). The role of forensic linguists in courtroom cross examinations. IFE Studies in English Language, 12(2), 1-12.

Satia, E. (2013). Strategies of controlling the linguistic response from cross-examined witnesses: Lay defendants as cross-examiners in a Kenyan resident magistrate's court. The University of Nairobi Journal of Language and Linguistics, 3, 28-51.

Stygall, G. (1994). Trial language: Differential discourse processing and discursive formation. Amsterdam/Philadelphia: John Benjamins.

Supardi, S. (2016). Language power in courtroom: The use of persuasive features in opening statement. Indonesian Journal of Applied Linguistics, 6(1), 70-78. https://doi.org/10.17509/ijal.v6il.2663

Susanto, S. (2016, May). Language in courtroom discourse. Paper presented at the Fourth International Conference on Education and Language ( $4^{\text {th }}$ ICEL). Bandar Lampung University, Bandar Lampung, Indonesia. 


\section{Epistemicity in Mubarak's and Al-Adly's Testimonies in the "Storming Prisons and Eastern Borders" case: The Knowing, Unknowing and Believing Positions}

Dr. Marwa Mohamed Khamis

مجلة وادي النيل للاراسات والبحوث الإنسانية والاجتماعية والتريوية (مجلة علمية محكمة)

Szczyrbak, M. (2013). "I think my own view is that..." On the linguistic construction of evidence in courtroom discourse. Topics in Linguistics, 12, 65-74.

Szczyrbak, M. (2014). Stancetaking strategies in judicial discourse: Evidence from US Supreme Court opinions. Studia Linguistica Universitatis Iagellonicae Cracoviensis, 131(1), 91-120.

Szczyrbak, M. (2018). Knowing, unknowing or believing? Epistemic stance in Donald Tusk's testimony in the trial on the Polish Air Force Tu-154 air crash. Studies in Polish Linguistics, 13(4), 209236.

Tehseem, T., \& Ali, I. (2015). Disqualifying a premier: A linguistic analysis of a legal narrative to unfold power. Asian Journal of Social Sciences \& Humanities, 4(2), 95-108.

Tkacukova, T. (2010). Representing oneself: Cross-examination questioning: Lay people as cross-examiners. In M. Coulthard \& A. Johnson (Eds.), The Routledge handbook of forensic linguistics (pp. 333-346). London: Routledge.

Toll, M., \& Shi, C. (2019, July). Knowledge and rhetoric: A specialization analysis of courtroom argumentation. Paper presented at the Third International Legitimation Code Theory Conference. University of the Witwatersrand, South Africa. Retrieved from academia.edu/38246717/Knowledge_and_Rhetoric_A_Specializ ation_Analysis_of_Courtroom_Argumentation

Toska, B. (2012). Epistemic hedges and boosters as stance markers in legal argumentative discourse. Topics in Linguistics, 10, 57-62.

Tracy, K. (2011). What's in a name? Stance markers in oral argument about marriage laws. Discourse and Communication, 5(1), 65-88.

Villanueva, V., \& Ranosa-Madrunio, M. (2016, July). Examining the language in the courtroom interrogation of vulnerable and nonvulnerable witnesses. Paper presented at the second Asian 
Regional Conference of the International Association of Forensic Linguistics. University of Santo Tomas, Manila, Philippines.

$\mathrm{Wu}, \mathrm{R}$. (2004). Stance in talk: A conversation analysis of Mandarian final particles. Amsterdam/Philadelphia: John Benjamins.

Zuczkowski, A. Bongelli, R., Vincze, L., \& Riccioni, I. (2014). Epistemic stance: Knowing, Unknowing and Believing (KUB) positions. In A. Zuczkowski, R. Bongelli, I. Riccioni, \& C. Canestrari (Eds.), Communicating certainty and uncertainty in medical, supportive and scientific contexts (pp. 115-136). Amsterdam/Philadelphia: John Benjamins.

\section{Internet Resources}

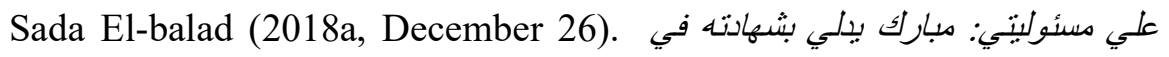
قضية اقتحام الحدودالثرقية بحضور المعزول مرسي (On my Responsibility: Mubarak testifies in the storming of Eastern borders case in the presence of ousted President Morsi) [Video]. YouTube. $\mathrm{https}: / / \mathrm{m}$.youtube.com/watch? $\mathrm{v}=9 \mathrm{wCVmf6UwW8}$

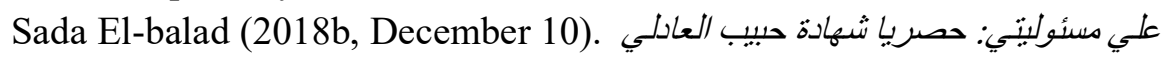
عن دخول عناصر أجنبية في قضبية اقتحام الحدود (On my Responsibility: Exclusive: Habib Al-Adly's testimony in "the storming of borders" case about the infiltration of foreign elements) [Video]. YouTube. https://m.youtube.com/watch?v=LNXipfLfLml 